Article

\title{
Perceptions of Priority Policy Areas and Interventions for Urban Sustainability in Polish Municipalities: Can Polish Cities Become Smart, Inclusive and Green?
}

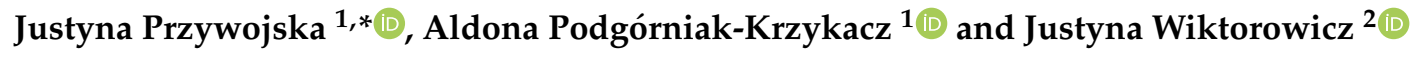 \\ 1 Department of Labour and Social Policy, University of Łódź; ul. Rewolucji 1905 r. nr 37, 90-214 Łódź, Poland \\ 2 Department of Economic and Social Statistics, University of Łódź; ul. Rewolucji 1905 r. nr 41, \\ 90-214 Łódź, Poland \\ * Correspondence: justyna.przywojska@uni.lodz.pl; Tel.: +48-42-635-52-44
}

Received: 12 April 2019; Accepted: 19 July 2019; Published: 21 July 2019

\begin{abstract}
The transition to sustainable urban development requires both appropriate city management and local authorities that are aware of the implications posed by new urban sustainability challenges. The article aims to identify the priority policy/practice areas and interventions to solve sustainability challenges in Polish municipalities, as well as the factors that differentiate these priorities. Through an online questionnaire we surveyed 460 Polish municipalities, and conducted a multidimensional assessment concerning how mayors (and their executive teams) prioritise possible policy/practice areas and interventions related to sustainability. Our analysis implies that the mayors (and their executive teams) assign higher priority to policy/practice areas and interventions related to economic and social domains, and slightly lower priority to environmental ones. However, an important finding is that the priority policy/practice areas and interventions do not correspond well to some of the contemporary sustainability challenges in Polish cities. Effectively tackling urban environmental, economic and social problems would require the implementation of new approaches related to smart cities, the circular economy and/or cultural diversity. However, these less traditional policy/practice areas and interventions are quite low on the priority list of Polish mayors and their executive teams. Interestingly mayors and executive teams that prefer more participatory and solidarity-based management approaches are more likely to prioritise less traditional policy/practice areas and interventions to solve urban sustainability challenges in their municipalities.
\end{abstract}

Keywords: sustainable cities; local government; local governance; urban policy priorities

\section{Introduction}

Many urban areas around the world currently experience various challenging and interdependent social, environmental, and economic sustainability problems, which vary substantially between contexts. For example, some experience rapid population increases (fueled sometimes by migration) or rapid population declines, ageing societies, urban decay, and environmental pollution [1-7]. These contemporary urban challenges are reflected in numerous scientific studies [8-10], as well as in the UN and EU policy agendas. For example, the 2030 Agenda for Sustainable Development [11] consolidated in 2015 these challenges in the 17 Sustainable Development Goals (SDGs) and 169 related targets, which reflect the three pillars of sustainable development, i.e., economic, environmental, and social sustainability. The SDG11 in particular focuses on how to enhance the sustainability and resilience of urban systems. From this starting point, the New Urban Agenda adopted in 2016 focused on the implementation of interventions to solve such sustainability challenges at the local level, indicating some of the key priority areas for contemporary urban development. These include, among others the 
(a) equal access to high quality public goods and services, (b) development of inclusive and socially engaged communities, (c) equality in diversity (including gender, age, ethnicity), (d) development of sustainable economies, (e) resilience of urban systems, (f) spatial planning and shaping public spaces with the involvement of diverse stakeholders, and (g) multi-level and multi-sectoral governance for urban sustainability [12].

Polish cities face many similar sustainability challenges for which they urgently need to find solutions. For example, issues of pollution, environmental protection and in-migration are particularly challenging in Poland. According to the WHO Global Urban Ambient Air Pollution Database, in 2018, 36 out of the 50 most polluted cities in the EU were located in Poland [13] (up from 33 cities in 2016 [14]). At the same time, Poland has transitioned from a migrant-sending economy, into an economy that is both migrant-sending and receiving $[15,16]$. The migration balance in 2014 amounted to $-15,750$, but in 2017 it amounted to +1436 people, suggesting a net migrant inflow in the country [17]. According to the Ministry of Investment and Economic Development, there are currently (in 2018) around 1 million employees from Eastern Europe working and living in Poland [18]. From a labour market perspective, this is beneficial since the rapidly ageing population leads to, among others, the decline of domestic labour availability. Compared to the EU average, Poland faces faster population ageing. The share of people aged $65+$ increased from $14.7 \%$ in 2013 to $32.7 \%$ in 2050, and the share of people over the age of 80 more than doubled in the same period [19]. Furthermore, the ageing society is accompanied by the depopulation of many Polish cities, a phenomenon that is also linked to the ongoing suburbanisation. The revitalisation and restoration of run-down urban areas (could reverse some of these trends, but might also have ramifications for social inclusion, gentrification and improvement in the quality of life. Since 2015, revitalisation has been an optional task for Polish municipalities. In 2016, revitalisation efforts spanned 288,385 ha, inhabited by 3,377,939 people [20]).

Most of the above challenges are clearly indicated in the national government's National Urban Policy 2023 strategy (PL: Krajowa Polityka Miejska 2023), a document defining the national government directions for sustainable urban development. This strategy identifies significant development priorities in several areas that are analogous to those discussed above: e.g., inclusive and sustainable spatial planning and land-use management; public participation; transport and urban mobility; low-carbon development and energy efficiency; revitalisation; investment policy; economic development; environmental protection and adaptation to climate change; demographic transitions; and urban area management [21].

However, transitioning to urban sustainability in Polish cities would require solving the challenges described above, possibly through the implementation of novel urban approaches such as: (a) smart cities, that promote the use of information and communication technologies to improve the quality of life [22-29], (b) green cities that emphasise on the natural environment and the rational use of its resources [30-37], (c) age-friendly cities, which target the demographic challenges posed by ageing societies [38], or (d) compact cities that limit urban sprawl, support the revitalisation and development of degraded areas, and prioritise pedestrians, public transport, cycling, while limiting the number of cars [39-43].

Regardless of the desired city vision (and its conceptual complexities), these current urban sustainability challenges indicate the need to develop strong and inclusive policies at the local government level. They require both proper management processes and city leaders that are not only aware of the importance of these challenges [44,45], but also willing to shape and implement sustainable urban development policies [46-48]. Local authorities are key for educating communities about these issues, and mobilising people to respond to local problems [49]. In this context the executive power of municipalities is integral for facilitating urban sustainability transitions.

In Poland, these executive powers are usually vested in mayors whose main statutory tasks include the: (a) implementation of municipal council resolutions, (b) implementation of city budgets, (c) management of the municipal property, (d) preparation of draft resolutions, (e) engagement, management and dismissal of the heads of local government agencies, and (f) coordination of activities 
among the different agencies. Mayors manage the day-to-day operations of the municipality, and act as representatives both within and outside their municipality (including internationally). One of the major roles of mayors is to oversee the operation and growth of their municipalities through the development and implementation of local strategies and programmes.

However, mayors are overseen by (and are accountable to) other municipal entities. In Poland, municipal councils are the regulatory authorities that hold accountable mayors (and their administration) in terms of their performance (e.g., through mandatory audit committees). Similar to mayors, municipal councils in Poland are elected through direct elections. The independence between executive bodies and municipal councils can be tracked to the introduction of the mayor system in 2002, and the Act on the direct election of the mayor. This policy essentially transformed the collective governing body within municipalities, moving from election through the municipality council (from 1990 to 2002), to a single-person body elected through direct elections. These audit committees review budget implementation and request the municipality council to either grant or refuse budget requests from the executive body (i.e., the regional chamber of audit decides whether to grant the budget). Other commissions within the municipality may also conduct control activities, but they have a limited ability to raise objections to the activities of the executive body. In a sense, mayors have more power for city issues compared to the rather limited control-balancing function of municipality councils [50]. The above suggest that mayors (and their executive teams) are the key players within local authorities in Poland, and can thus play a major role in steering municipalities towards sustainability.

The aim of the article is to identify the perception of mayors (and their executive teams) on the priority policy/practice areas and interventions needed to tackle sustainability challenges in Polish municipalities, and the factors differentiating these priorities. To achieve this, we conduct an online survey with representatives from different Polish municipalities on how they prioritise a series of possible policy areas and interventions. We then study how different factors such as the characteristics of the municipalities or the preferred management style affect these priorities. Section 2 outlines the methodology of this study, including the hypotheses, and data collection and analysis approaches. Section 3 presents the main results and Section 4 synthesises the main findings, interprets research results in the context of other studies, and indicates the implications for public policy.

\section{Methodology}

\subsection{Research Approach}

We start from the findings of previous studies about the state of local government in Poland [50]. In particular, following the existing evidence, our key assumption is that Polish mayors (and their executive teams) are not aware of the significance and possible implications of the new urban sustainability challenges in Poland. This lack of awareness affects how mayors (and their executive teams) prioritise policy/practice areas and interventions to solve effectively and inclusively such sustainability challenges. Based on the above, we form two hypotheses:

- (H1) Mayors (and executive teams) in municipalities with a significant concentration of administrative, social and economic functions (e.g., cities with district rights, larger financial resources) prioritise less traditional policy/practice areas and interventions that are more fit to tackle new urban sustainability challenges;

- (H2) Mayors (and executive teams) who adopt more participatory and solidarity-based management approaches, in contrast to mayors who identify themselves with other analyzed management styles, are more likely to prioritise less traditional policy/practice areas and interventions in order to solve emerging urban sustainability challenges.

(H1) is based on the findings of previous reports on the state of local governments in Poland, which identify that the major cities are more successful due to their significant resources [50]. This includes only a few large cities such as Warsaw, Wrocław, Gdańsk, and Poznań where living standards are very close to those of cities in Western Europe [51]. In these areas, large companies, generate knowledge, 
information, and innovations, and are major driving forces in urban development [50]. On the contrary the development levels of many other Polish municipalities are quite low [50-52]. From this staring point it can be argued that the type and wealth of municipalities indicate the sustainability challenges they face, as well as how they attempt to solve them. Based on this we assume that these factors also influence the way that mayors (and their executive teams) prioritise less traditional policy/practice areas and interventions that are possibly more fit to tackle new urban sustainability challenges. These include policy/practice areas and interventions related to the circular economy, diversity management or harnessing the technological revolution. On the other hand, smaller and less endowed cities struggle with more traditional sustainability challenges and are affected by shortages in technical and social infrastructure and/or low levels of entrepreneurship, which eventually affects how they approach urban sustainability (see also [53]).

$(\mathrm{H} 2)$ rests on our belief that an effective transformation towards sustainable urban development needs to consider contemporary megatrends, and would require changes in the style of political leadership in municipalities. In particular, there is a need for city leaders to be more open towards participation, dialogue and close cooperation with the private sector, civil society and the public. This would require the adoption and implementation of responsible, just, joint and tolerant management approaches. Many scholars have indicated the importance of cooperation for the effective 'management' of transitions towards sustainable development [54-58], and the need for sustainable governance [59]. In a sense, inter-generational equity, inclusiveness, and broad stakeholder participation reflect the concept of "homo cooperativus", which sits at the core of sustainable development [60]. To study these two hypotheses our research follows the four basic stages outlined in Figure 1.

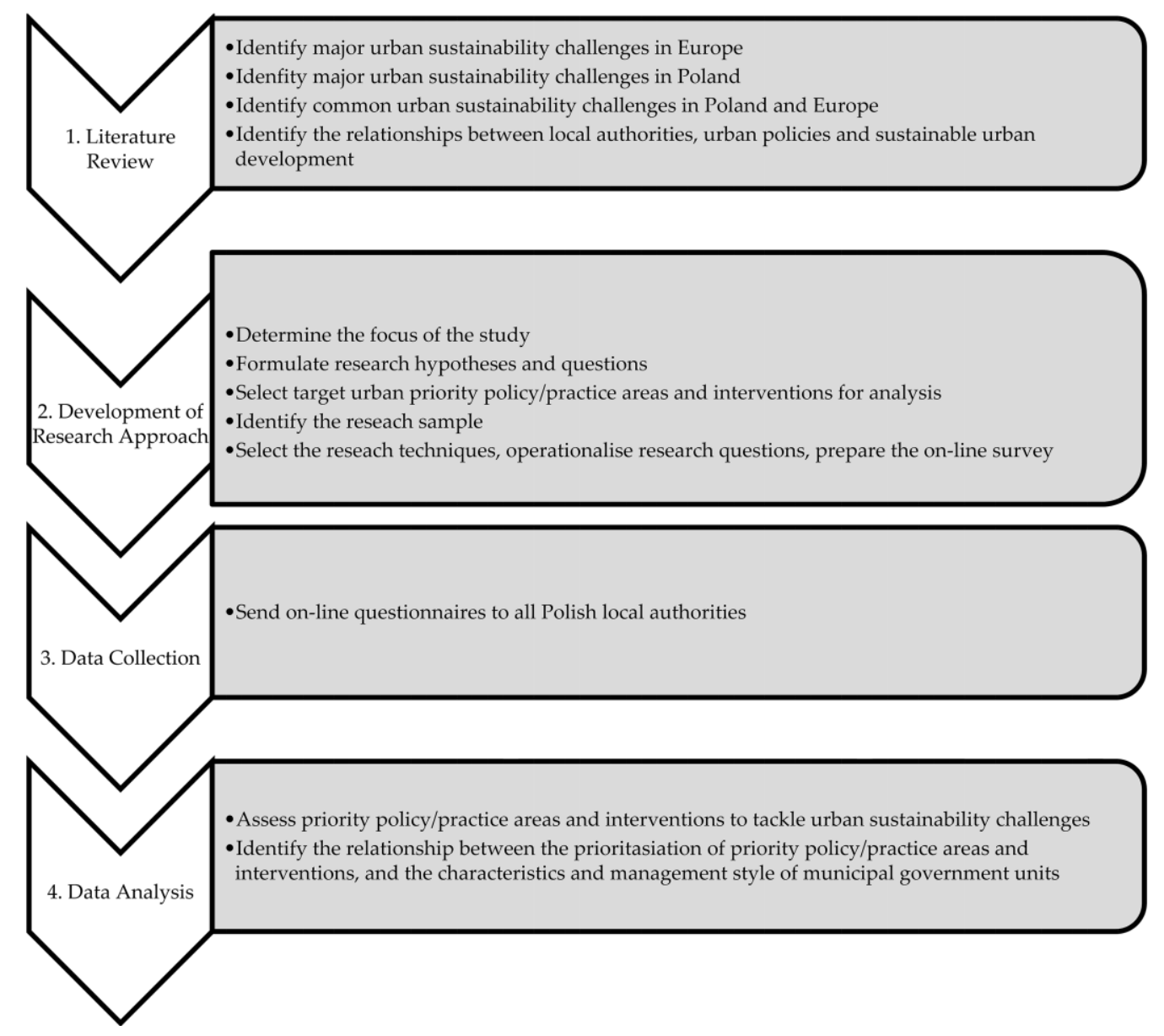

Figure 1. Research stages. 
Stage 1 entails a literature review that identifies the main contemporary urban sustainability challenges and their relevance in Poland. The main findings of Stage 1 are presented in Section 1, and are used to inform the subsequent assessment (Stages 2-4).

Stage 2 entails the formulation of the research hypotheses outlined above. In particular we focus on 11 potential policy/practice areas and interventions for urban sustainability challenges, six of which are chosen based on the political priorities of EU local government leaders (as identified by the Polleader research network [61,62]) and five based on the literature review carried out during Stage 1 (See Section 2.2).

Stage 3 entails the development of a data collection protocol, and an online survey with Polish municipalities, targeting mayors (and their executive teams) (Section 2.2)

Stage 4 involves the analysis of the data collected through the survey using different statistical techniques (Section 2.3).

\subsection{Data Collection}

Based on the literature review (Stage 1) we construct a survey consisting of two main parts. The first part aims to elicit the perception of mayors (and their executive teams) about 11 possible policy/practice areas and interventions, that can tackle some of the main urban sustainability challenges facing Polish cities (Section 1), namely:

- Improving local infrastructure, communication and transport;

- Encouraging economic growth/employment, attracting investors, and creating investment opportunities;

- Developing social policies that ensure the appropriate housing, health care, education, and cultural needs of vulnerable social groups (e.g., elderly, young, unemployed);

- Promoting environmental protection, and the safe and responsible use of natural resources;

- Solving political and administrative problems (e.g., improve relations with citizens, improve/enhance the effectiveness of public services, fight corruption);

- Improving the integration of minorities (e.g., ethnic, religious, cultural), and promoting diversity and tolerance within local communities;

- Revitalising run-down areas through the modernisation and renovation of buildings and infrastructure;

- Revitalising degraded areas through investments in human and social capital;

- Shaping municipal closed-loop economies (i.e., circular economy approaches);

- Implementing smart city concepts;

- Responding to global trends (e.g., technological revolution).

The perceptions about the priority assigned to the 11 policy/practice areas and interventions were captured through a five-point Likert scale ranging from: $1=$ low priority, to $5=$ high priority. Following this, we identify three factors that can affect the prioritization of the above policy/practice areas and interventions within municipalities; namely the (a) type of municipality, (b) affluence of municipality, and (c) management style preferred by the mayor (and the executive team).

The type of municipality used in this study, reflects the current typology of municipalities with a city area within their boundaries in Poland: i.e., (a) cities with district rights, (b) urban municipalities, and (c) urban-rural municipalities. In 2018, there were 921 such municipalities $(37.2 \%$ of all 2478 municipalities, including the rural ones), including 66 cities with district rights ( $2.7 \%$ of all municipalities), 237 urban municipalities ( $9.6 \%$ of all municipalities) and 618 urban-rural municipalities (24.9\% of all municipalities). In Poland, the types of gminas (communes), as well as municipal and rural areas, are differentiated in public statistics. They are based on the national territorial division and related identifiers articulated in the Polish National Official Register of the Territorial Division of the Country (TERYT). This official division is based exclusively on the administrative criteria set in the “Regulation of the Council of Ministers of December 15th 1998 on detailed principles of running, using 
and making available the territorial register and related to it obligations of the state administration agencies and self-government entities" (Journal of Laws of 1998 No. 157, item 1031). Based on this regulation, there are three distinct types of gminas (communes):

- urban municipalities, whose administrative boundaries match the boundaries of cities (i.e., urban municipalities, but can also be cities with district rights);

- urban-rural municipalities, which include within their administrative boundaries both city/town areas, as well as areas outside city limits;

- rural gminas (rural communes), which do not have any city/town areas within their administrative boundaries.

Municipality affluence is expressed through the municipal budget revenues in 2016. These municipal budget revenues are obtained through (a) own municipality income (including municipal taxes/fees, income from assets, income obtained by local government agencies, shares in income tax on natural and legal persons), disbursement from national government budget, EU funds, loans, securities and bonds. Data on budget revenue was obtained through surveys.

The management style was also perceived as an important factor influences the prioritization and selection of urban development interventions [63]. We identify five management styles, namely: (1) a loyal politician who implements the objectives of his/her political party; (2) a visionary and strategist who incorporates a long-term perspective into municipal management; (3) an efficient manager who manages the municipality; (4) an initiator/coordinator who shapes relationships, cooperation and networks in city management; and (5) a leader guided by the common interest and solidarity $[60,64]$. Respondents expressed their preferences for these management styles through a five-point Likert scale, where $(1=$ definitely disagree with the specific style, to $5=$ definitely agree with the specific style).

The survey was carried through an on-line questionnaire that was sent through an invitation to participate in the study and a request for access to public information. The invitation and request were sent to all 921 municipalities described above, with the respondents having the opportunity to fill in the form online or return it by post or email. The questionnaire was addressed to the executive bodies (i.e., mayors), their deputies and secretaries since they have the greatest influence shaping and implementing local policies. The study was carried out between June and October 2017 (i.e., before the last local government elections in Poland: October to November 2018).

\subsection{Data Analysis}

Questionnaire data was analysed using basic descriptive statistics, the Kruskal-Wallis test, the Pearson correlation or the Spearman's rank correlation. The significance of correlation coefficients was assessed using the t-test. These methods are used to identify the relationship between the prioritization of different policy/practice areas and interventions and the factors outlined in Section 2.2, i.e., municipality characteristics (type, affluence), and the preferred management style.

We also undertake an exploratory factor analysis (EFA) and estimate Cronbach's alpha to group the different policy/practice areas and interventions into clusters that reflect a similar level of importance as perceived by respondents. The EFA groups variables in homogeneous classes, and requires an adequately large sample, i.e., above 300 [65]. Alternatively, the number of variables (p)-the most popular ratio N:p (STV ratio) is 5:1 (or 10:1)—is considered at this stage of analysis [66]. Data adequacy for the EFA is usually evaluated through the Kaiser-Meyer-Olkin (KMO) measure and Bartlett's test of sphericity. A KMO value $>0.5$ is acceptable [67], while the Bartlett's test of sphericity should be statistically significant $(p<0.05)$. Following the EFA the number of factors is selected though criteria such as: (i) the Kaiser rule (i.e., retain only those factors with an eigenvalue larger than 1), (ii) the Cattell criterion (i.e., a scree-plot) [68]. Additionally, the diagonal elements of the inverse correlation matrix, [also known as the variance inflation factors (VIF)], should be $<10$, as this would indicate that the correlation between variables is not too strong. 
We use principal component analysis (PCA), which is an adaptation of Hotelling's principal component analysis for the EFA [69]. Subsequently we select the rotation method, whose goal is to simplify and clarify the data structure [70]. The most popular rotation method is varimax (which like to quartimax and equamax), is an orthogonal method of rotation (oblimin, quartimin and promax are oblique and allow the coefficient to be correlated) (see, e.g., [71]). There is no widely preferred method of oblique rotation, as all of the main methods tend to produce similar results [72]. In this paper, we use the equamax technique, albeit other rotation methods led to the same subgroups. On the basis of the values of factor loadings we are able to indicate the variables of significant importance, which should be above \pm 0.5 .

On the basis of the EFA results, we calculate indices (W1-3). These indices are created as the sum of points for the variables in each area. Reliability for these indices is evaluated using Cronbach's alpha, with a value of $>0.7$ indicating good reliability. Additionally, for split-half reliability assessment, we use the Spearman-Brown prediction formula and the Guttman split reliability coefficient. For all calculations, we adopt a standard level of significance $(\alpha=0.05)$. The calculations are performed in PS IMAGO SPSS 4.0 (Version4.0, Predictive Solutions, Krakow, Poland).

\section{Results}

\subsection{Sample Characteristics}

Overall 460 out of the 921 Polish municipalities with a city area within their boundaries participated in the research (Section 2.2). The make out of the research sample (Table 1) reflects well the division of municipalities with a city within their administrative boundaries in Poland (Section 2.2). Only urban-rural municipalities are slightly underrepresented in our sample (Table 1, Figure 2).

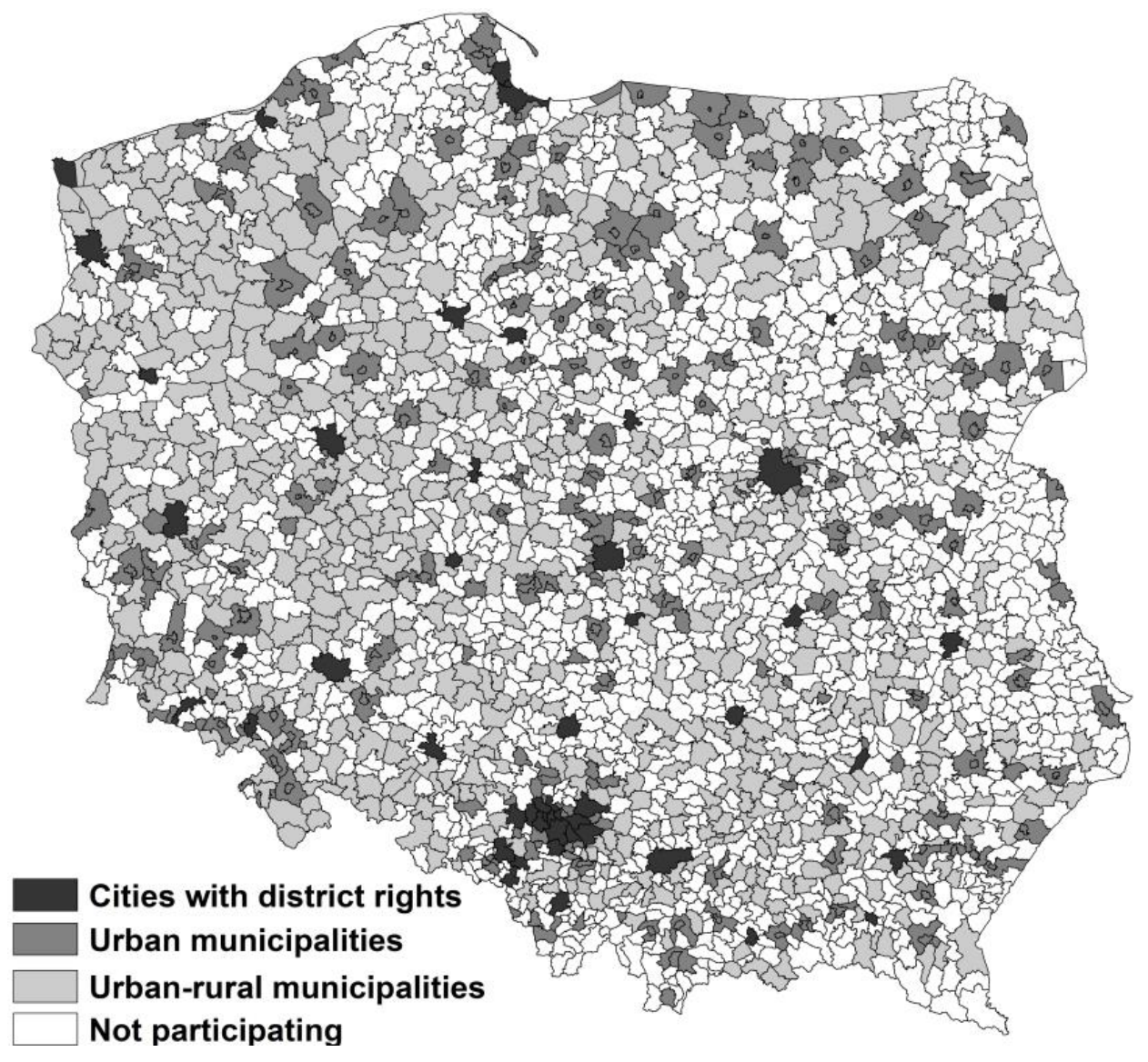

Figure 2. Spatial distribution of the study municipalities. 
Table 1. Types of municipalities in the study sample.

\begin{tabular}{lcc}
\hline \multicolumn{1}{c}{ Type } & n & \% \\
\hline Cities with district rights (CDR) & 42 & 9.1 \\
Urban municipalities (UM) & 144 & 31.3 \\
Urban-rural municipalities (URM) & 274 & 59.6 \\
Total & 460 & 100.0 \\
\hline
\end{tabular}

Regarding their affluence, most municipalities have budget revenues below USD 13.78 million (PLN 50 million; PLN-Polish zloty) (Table 2). Few municipalities exceed budget revenues of USD 137.85 million (PLN 500 million). The most affluent municipalities have budget revenues of over USD 275.7 million (PLN 1 billion). The median budget revenue is USD 14.2 million (PLN 51.6 million).

Table 2. Budget revenues for the study municipalities.

\begin{tabular}{ccc}
\hline 2016 Budget Revenue (in mil PLN) & n & \% \\
\hline Below 50 & 210 & 45.5 \\
$50-100$ & 125 & 27.2 \\
$100-500$ & 81 & 17.7 \\
Over 500 & 40 & 8.7 \\
Note: 1 mil PLN = (approx.) 275,700 USD (exchange rate: 13th June 2018). & 4 & 0.9 \\
\cline { 2 - 3 }
\end{tabular}

When it comes to the actual respondents, $14.8 \%$ are mayors, $12.0 \%$ deputies, $45.9 \%$ secretaries, and the remainder have another role within the committee, but have sufficient knowledge of the study subject and were authorised by the respective mayors. However, to answer the questions relating to the mayors' opinions and their professional experience (Section 2.2), the direct involvement of the mayors was required. In most study municipalities (approx. $75 \%$ ) mayors do not represent any political party (i.e., they are proposed by either the electoral committee of the local association, or the voters' committee.

\subsection{Perspectives of the Priority Policy/Practice Areas and Interventions}

Table 3 presents the perceptions of respondents about the prioritized policy/practice areas and interventions (columns 1-5 correspond to the Likert-scale scores). The results clearly reflect both the prioritisation of traditional approaches to sustainable development, and the markedly low interest in new policy/practice areas and interventions. In particular, the top five priorities mostly include reactive and corrective approaches related to the economy such as (a) improving infrastructure $(\mathrm{Me}=5$; $62.8 \%$ of the respondents scored 5 ), (b) stimulating economic growth ( $\mathrm{Me}=5 ; 63.7 \%$ of the respondents scored 5), and (c) revitalising degraded areas through building and infrastructure modernisation and renovation ( $\mathrm{Me}=4$ points; $45.0 \%$ of respondents scored 5$)$. A median score of 5 was also obtained for some social policy/practice areas and interventions such as the development of social policies $(\mathrm{Me}=5$; $53.7 \%$ of respondents scored 5). Though rated lower, the group of the five most important priorities also contains approaches related to the environment such as promoting environmental protection and the safe and responsible use of natural resources ( $\mathrm{Me}=4 ; 40.2 \%$ of respondents scored 5). Areas related to more novel approaches or emerging sustainability issues such as (a) implementing smart city concepts ( $\mathrm{Me}=3, \mathrm{M}=3.15)$, (b) responding to global trends (technological revolution) $(\mathrm{Me}=3$, $\mathrm{M}=3.11$ ) or (c) improving the integration of minorities $(\mathrm{Me}=3, \mathrm{M}=3.01)$, were relegated almost to the bottom of the municipal priorities. 
Table 3. Perceptions about individual priority policy/practice areas and interventions.

\begin{tabular}{|c|c|c|c|c|c|c|c|c|}
\hline Priority Policy/Practice Areas and & 1 & 2 & 3 & 4 & 5 & $\begin{array}{c}\text { No } \\
\text { Answer }\end{array}$ & $\mathrm{Me}$ & $\mathbf{M}$ \\
\hline & \multicolumn{6}{|c|}{$(\% ; n=460)$} & \multicolumn{2}{|c|}{ In Points } \\
\hline $\begin{array}{l}\text { Improving local infrastructure, } \\
\text { communication and transport }\end{array}$ & 0.2 & 0.4 & 3.5 & 24.6 & 62.8 & 8.5 & 5.00 & 4.63 \\
\hline $\begin{array}{l}\text { Encouraging economic growth/employment, } \\
\text { attracting investors, creating investment } \\
\text { opportunities }\end{array}$ & 0.4 & 0.7 & 5.0 & 21.5 & 63.7 & 8.7 & 5.00 & 4.61 \\
\hline $\begin{array}{l}\text { Developing social policies that ensure the } \\
\text { appropriate housing, health care, education, } \\
\text { and cultural needs of vulnerable social groups } \\
\text { (e.g., elderly, young, unemployed) }\end{array}$ & 0.2 & 1.1 & 5.9 & 29.8 & 53.7 & 9.3 & 5.00 & 4.50 \\
\hline $\begin{array}{l}\text { Revitalising run-down areas through the } \\
\text { modernisation and renovation of buildings } \\
\text { and infrastructure }\end{array}$ & 1.1 & 0.9 & 11.1 & 33.3 & 45.0 & 8.7 & 4.00 & 4.32 \\
\hline $\begin{array}{l}\text { Promoting environmental protection and the } \\
\text { safe and responsible use of natural resources }\end{array}$ & 0.0 & 1.3 & 11.7 & 38.0 & 40.2 & 8.7 & 4.00 & 4.28 \\
\hline $\begin{array}{l}\text { Revitalising degraded areas through } \\
\text { investments in human and social capital }\end{array}$ & 1.1 & 3.3 & 16.7 & 35.4 & 34.1 & 9.3 & 4.00 & 4.08 \\
\hline $\begin{array}{l}\text { Solving political and administrative problems } \\
\text { (e.g., improve relations with citizens, } \\
\text { improve/enhance the effectiveness of public } \\
\text { services, fight corruption) }\end{array}$ & 0.4 & 3.0 & 20.0 & 39.6 & 27.4 & 9.6 & 4.00 & 4.00 \\
\hline $\begin{array}{l}\text { Shaping municipal closed-loop economies } \\
\text { (i.e., circular economy approaches) }\end{array}$ & 0.9 & 3.7 & 28.0 & 43.0 & 13.7 & 10.7 & 4.00 & 3.73 \\
\hline Implementing smart city concepts & 7.4 & 14.6 & 33.9 & 26.3 & 8.3 & 9.6 & 3.00 & 3.15 \\
\hline $\begin{array}{l}\text { Responding to global trends } \\
\text { (e.g., technological revolution) }\end{array}$ & 6.3 & 16.1 & 35.0 & 27.8 & 5.7 & 9.1 & 3.00 & 3.11 \\
\hline $\begin{array}{l}\text { Improving the integration of minorities } \\
\text { (e.g., ethnic, religious, cultural), and } \\
\text { promoting diversity and tolerance within local } \\
\text { communities }\end{array}$ & 11.5 & 15.7 & 31.3 & 24.1 & 7.8 & 9.6 & 3.00 & 3.01 \\
\hline
\end{tabular}

Note: Me denotes median; M denotes mean; “No answer" omitted.

Subsequently we test whether there are any patterns in the prioritisation of policy/practice areas and interventions by the mayors (and their executive teams). We analyse the internal structure of these priority perceptions to evaluate the homogeneity of the different components, i.e., the 11 variables describing urban policy/practice areas and interventions used to tackle urban sustainability challenges. We use Exploratory Factor Analysis (EFA) below to identify distinct sub-dimensions among respondents' perceptions regarding the prioritized policy/practice areas and interventions (Section 2.3). In other words, EFA is used to determine the latent structure of respondents' perspectives and reduce the original set of variables (i.e., priorities) to a small set of underlying factors (i.e., clusters of priorities) that reflect the essential information of the variables. In our study these factors essentially capture the main-from the point of view of tackling urban sustainability challenges-groups (clusters) of policy/practice areas and intervention, which explain the relationship between the 11 original measureable priority areas and interventions.

Table 4 identifies three clusters of policy/practice areas and interventions (three factors), namely "new perspectives" (W1), "traditionalist perspective" (W2), "reactive perspectives" (W3). These factors reflect a relatively significant part of the focus of their individual variables, but at the same time they also reflect distinct overarching priority approaches. When taking into consideration the percentage of variance explained by a particular factor it is possible to determine its significance for tackling urban sustainability challenges. In this context, W1 ("new perspectives towards urban sustainability 
priorities") is the main factor for contemporary Polish cities and has the highest significance for tackling urban sustainability challenges in the country.

Table 4. Distribution of policy/practice areas and interventions between the three factors.

\begin{tabular}{|c|c|c|c|c|}
\hline \multirow{2}{*}{ Priority Policy/Practice Areas and Interventions } & \multicolumn{3}{|c|}{ Factor } & \multirow{2}{*}{$\mathrm{C}^{3}$} \\
\hline & W1 & W2 & W3 & \\
\hline Responding to global trends (e.g., technological revolution) & 0.827 & 0.278 & 0.133 & 0.779 \\
\hline $\begin{array}{l}\text { Improving the integration of minorities (e.g., ethnic, religious, cultural), } \\
\text { and promoting diversity and tolerance within local communities }\end{array}$ & 0.783 & 0.169 & 0.244 & 0.701 \\
\hline Implementing smart city concepts & 0.777 & 0.185 & 0.197 & 0.677 \\
\hline $\begin{array}{l}\text { Promoting environmental protection and the safe and responsible use of } \\
\text { natural resources }\end{array}$ & 0.212 & 0.750 & 0.072 & 0.613 \\
\hline $\begin{array}{l}\text { Developing social policies that ensure the appropriate housing, health } \\
\text { care, education, and cultural needs of vulnerable social groups (e.g., } \\
\text { elderly, young, unemployed) }\end{array}$ & 0.144 & 0.687 & 0.181 & 0.525 \\
\hline $\begin{array}{l}\text { Shaping municipal closed-loop economies (i.e., circular economy } \\
\text { approaches) }\end{array}$ & 0.414 & 0.552 & -0.009 & 0.477 \\
\hline $\begin{array}{l}\text { Solving political and administrative problems (e.g., improve relations } \\
\text { with citizens, improve/enhance the effectiveness of public services, fight } \\
\text { corruption) }\end{array}$ & 0.423 & 0.541 & 0.144 & 0.492 \\
\hline $\begin{array}{l}\text { Encouraging economic growth/employment, attracting investors, } \\
\text { creating investment opportunities }\end{array}$ & 0.152 & 0.524 & 0.237 & 0.354 \\
\hline $\begin{array}{l}\text { Revitalising run-down areas through the modernisation and renovation } \\
\text { of buildings and infrastructure }\end{array}$ & 0.139 & 0.097 & 0.885 & 0.813 \\
\hline $\begin{array}{l}\text { Revitalising degraded areas through investments in human and social } \\
\text { capital }\end{array}$ & 0.386 & 0.021 & 0.811 & 0.806 \\
\hline Improving local infrastructure, communication and transport & -0.024 & 0.451 & 0.576 & 0.536 \\
\hline$\%$ of total variance explained by factors & 40.22 & 11.73 & 9.61 & $\mathrm{x}$ \\
\hline Cumulative variance $(\%)$ & 40.22 & 51.95 & 61.56 & $x$ \\
\hline Reliability: Cronbach's alpha & 0.818 & 0.727 & 0.736 & $\mathrm{x}$ \\
\hline Spearman-Brown coefficient (non-equal length) & 0.806 & 0.732 & 0.801 & $\mathrm{x}$ \\
\hline Guttman split reliability coefficient & 0.710 & 0.697 & 0.767 & $x$ \\
\hline
\end{tabular}

Note: $\mathrm{KMO}=0.840$; Bartlett's sphericity test: $\chi^{2}=1529.7, \mathrm{df}=55, p<0.0001^{*}$. Factor loadings for the factor for which each variable is most strongly related have been marked in bold. $\mathrm{C}$ denotes communalities.

The first factor (W1) includes three of the less traditional types of policy/practice areas and interventions: namely (a) "responding to global trends (e.g., technological revolution)", (b) "improving the integration of minorities (e.g., ethnic, religious, cultural), and (c) promoting diversity and tolerance within local communities" and "implementing smart city concepts". This factor explains the variance of the latent variable at $40.22 \%$. Respondents giving higher scores on the priorities captured by first factor (thus resulting in a higher value for W1 index), tend to prioritize policy/practice areas and interventions related to the new urban challenges.

The second factor (W2) contains the largest number of policy/practice areas and interventions: namely (a) "promoting environmental protection and the safe and responsible use of natural resources"; (b) "developing social policies that ensure the appropriate housing, health care, education, and cultural needs of vulnerable social groups", (c) "shaping municipal closed-loop economies (i.e., circular economy approaches)", (d) "solving political and administrative problems", (e) "encouraging economic growth/employment, attracting investors and creating investment opportunities". This factor explains $11.73 \%$ of the latent variable. Respondents giving a higher score for this factor (thus resulting in a 
higher value for W2 index) tend to prioritize more traditional policy/practice areas and interventions, which implies that they rather focus on some of the more traditional challenges of sustainable urban development.

The third factor (W3) consists of three policy/practice areas and interventions: namely (a) "revitalising run-down areas through the modernisation and renovation of buildings and infrastructure"; (b) "revitalising degraded areas through investments in human and social capital" and (c) "improving local infrastructure, communication and transport". This factor explains nearly $10 \%$ of the variance of the latent variable, and reflects a rather reactive perspective towards urban sustainability priorities.

Both KMO and Bartlett's sphericity test indicate the good properties of the 11 variables, in terms of the adequacy for EFA use (Table 4) (Section 2.3). Additionally, for all variables, the VIF is below 10, and even lower than 2.5. Factor loadings marked in bold exceed the value of 0.5 and are positive, which not only does it indicate a high positive correlation between the included variables weighing a given factor, but also confirms that their inclusion is appropriate. Each of these factors is characterised by high reliability, and therefore can be used to construct W1, W2 and W3 indices. The indices describe in a one-dimensional way each of the different sub-dimensions of tackling urban sustainability challenges. Scores for the W1 and W3 indices can range between 3 and 15, while for the W2 index scores can range between 5 and 25. For the studied cities, only the index W2 does not reach the minimum value possible (i.e., the results are not below 12 points), see Table 5 .

Table 5. Descriptive statistics for W1-W3 indices and their correlations.

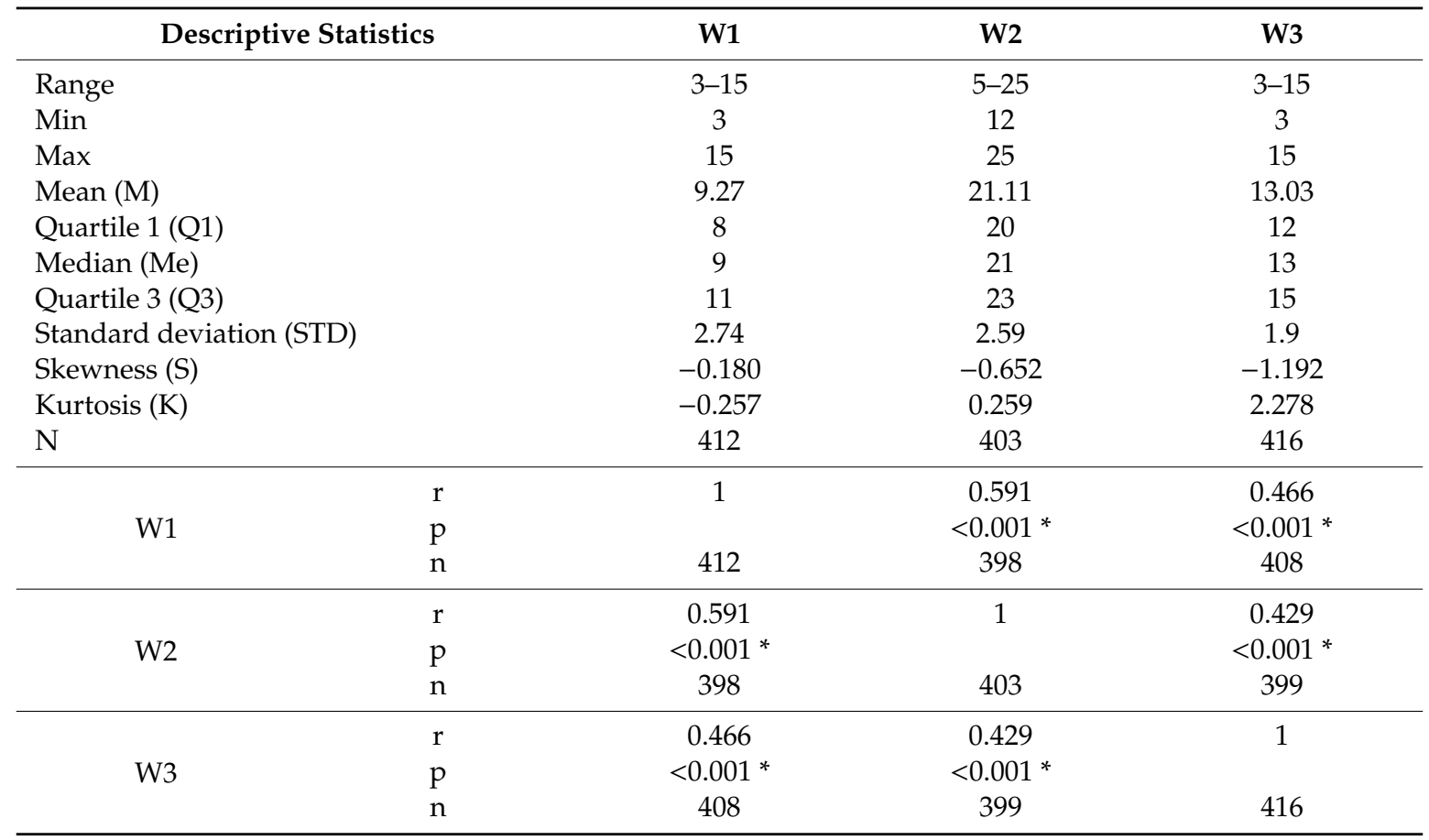

Note: $p<0.0001^{*}$.

Regarding the W1 index, 25\% of respondents have scored 8 or below (Q1), 50\% have scored 9 or more. and $25 \%$ have scored 11 or more (Q3) (Table 5). The average rating is 9.27 with a relatively good similarity of the results across the entire sample ( $\mathrm{STD}=2.74)$. The distribution is close to normal, as suggested in the histogram (Figure 3), the value of kurtosis and the coefficient of skewness (both close to zero) (Table 5). The above suggest that the respondents' perceptions of priority policies/practices and interventions from the initial sub-dimension are at a moderate level, with small diversity in relation to the mean. 


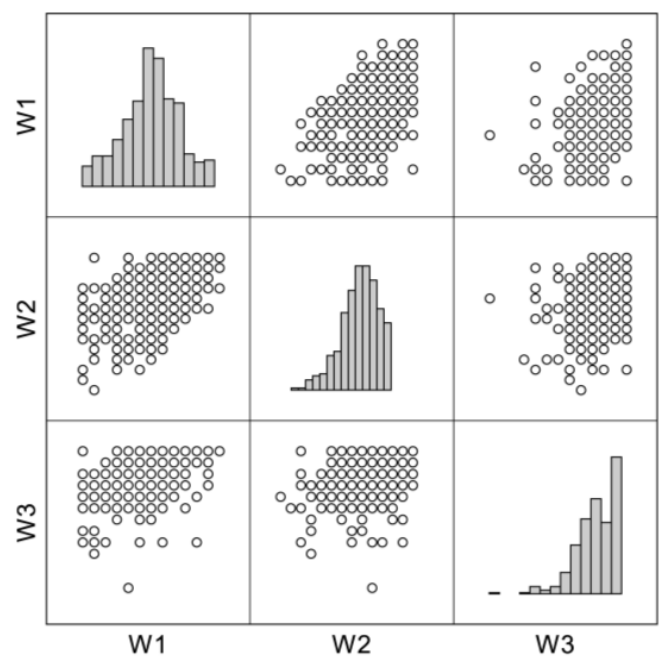

Figure 3. Scatterplots and histograms for the three indices (W1-W3).

Similar conclusions can be drawn and for the W2 index. Even though the value and the range of variability of W2 is higher, the results suggest that respondents' opinions are also poorly diversified in the way they prioritise the "traditionalist perspective towards urban sustainability priorities". For half of the most typical cities in our sample, the score of the W2 index falls within a very short interval (i.e., between 20-23 points), and has a low standard deviation (Table 5). In this case, a slightly stronger negative skewness is observed (i.e., the occurrence of atypically low assessments, Figure 3).

Conversely, the W3 index exhibits a stronger negative skewness. In particular, $25 \%$ of respondents have scored 12 or less (Q1), 50\% 13 or more (Me) and 25\% 15 or more (Q3), with the maximum score being at the same level as for the W1 (i.e., 15 points). The average rating is 13.03 with a large similarity of results in the entire population $(\mathrm{STD}=1.90)$. These scores suggest that priorities related to regeneration are important, but for some municipalities the significance is lower than for most municipalities (i.e., the range between minimum and the first quartile equals to 9 points, while the range is 14 points).

However, in order to compare the importance of the intervention clusters according to respondents' responses (and taking into account the different number of interventions constituting the three indices) it is better to calculate the indices as a mean rather than as the sum of individual ratings (i.e., the indices range of these indices is from 1 to 5 ). Then, policies/practices/interventions in the W1 index are the lowest priority among mayors and their executive teams, as the median score is 3 compared to 4.2 for W2, and 4.33 for W3. Furthermore, it also has the lowest mean: for W1 M = 3.09, STD = 0.91; for $\mathrm{W} 2 \mathrm{M}=4.22$, STD $=0.52$; for $\mathrm{W} 3 \mathrm{M}=4.33$, STD = 0.64). Both the standard deviation and the range (including quadrant range) suggest that the most homogeneous cluster of policy/practices areas and interventions in Polish cities occurs in the second analysed sub-dimension, i.e., "traditionalist perspective towards urban sustainability priorities".

The policy/practice areas and interventions related to urban regeneration (W3) are the most prioritized among Polish mayors and their executive teams. The mean and median rating is 4.33 and, the value of quartile 3 (Q3) corresponds to the maximum score (5 points). This rating relates to $30 \%$ of the sampled cities, while for W2 and W1 it relates only to $9 \%$ and $3 \%$ of the cities respectively. Thus, this area, though relatively less significant from the perspective of tackling urban sustainability challenges (i.e., the lowest contribution to the explanation of the latent variable), has been prioritized the most among mayors (and their executive teams).

Correlations between the three calculated three indices are statistically significant and positive. Both the scatterplot (Figure 3) and the value of the correlation coefficient (right part of Table 4) confirm the relatively strong relationship between indices W1 and W2 $\left(\mathrm{r}=0.591, p<0.001^{*}\right)$. Although, the correlation between other indices is also statistically significant and positive, it is slightly weaker. This 
suggests that more modern approaches are more typically prioritised for these municipalities in which mayors (and their executive teams) prioritise also traditional policy/practice areas and interventions.

\subsection{Effect of Municipality Characteristics on the Prioritization of Policy/Practice Areas and Interventions}

The prioritization of policy/practice areas and interventions is, to a certain extent, related to the characteristics of municipalities. Table 6 shows the relationship between the 11 priorities and the type of municipality (Table 6) and its wealth as measured by budget revenues (Table 7). The column headings (score 1-5) in both tables correspond to the priority levels elicited through the Likert scale (Section 2.2).

Table 6. Prioritization of policy/practice areas and interventions by type of municipality.

\begin{tabular}{|c|c|c|c|c|c|c|c|c|c|}
\hline \multirow{2}{*}{$\begin{array}{l}\text { Priority Policy/Practice Areas and } \\
\text { Interventions }\end{array}$} & \multirow{2}{*}{$\begin{array}{l}\text { LGU } \\
\text { Type }\end{array}$} & 1 & 2 & 3 & 4 & 5 & $\mathbf{M}^{1}$ & $\mathrm{Me}^{2}$ & \multirow{2}{*}{$\mathrm{p}^{3}$} \\
\hline & & \multicolumn{5}{|c|}{$\begin{array}{l}(\% ; \text { Number of LGUs of the } \\
\text { Given Type }=100)\end{array}$} & \multicolumn{2}{|c|}{ Points } & \\
\hline \multirow{3}{*}{$\begin{array}{l}\text { Developing social policies that ensure the } \\
\text { appropriate housing, health care, education, and } \\
\text { cultural needs of vulnerable social groups (e.g., } \\
\text { elderly, young, unemployed) }\end{array}$} & $\begin{array}{c}\text { CDR } \\
(\mathrm{N}=42)\end{array}$ & & & 9.4 & 18.8 & 71.9 & 4.63 & 5.00 & \multirow{3}{*}{0.361} \\
\hline & $\begin{array}{c}\mathrm{UM} \\
(\mathrm{N}=144)\end{array}$ & & 1.5 & 6.1 & 32.1 & 60.3 & 4.51 & 5.00 & \\
\hline & $\begin{array}{c}\text { URM } \\
(\mathrm{N}=274)\end{array}$ & 0.4 & 1.2 & 6.3 & 35.0 & 57.1 & 4.47 & 5.00 & \\
\hline \multirow{3}{*}{$\begin{array}{l}\text { Promoting environmental protection and the } \\
\text { safe and responsible use of natural resources }\end{array}$} & CDR & & 3.2 & 12.9 & 35.5 & 48.4 & 4.29 & 4.00 & \multirow{3}{*}{0.650} \\
\hline & UM & & 1.5 & 16.7 & 39.4 & 42.4 & 4.23 & 4.00 & \\
\hline & URM & & 1.2 & 10.9 & 43.6 & 44.4 & 4.31 & 4.00 & \\
\hline \multirow{3}{*}{$\begin{array}{l}\text { Shaping municipal closed-loop economies (i.e., } \\
\text { circular economy approaches)) }\end{array}$} & CDR & 6.7 & 13.3 & 20.0 & 43.3 & 16.7 & 3.50 & 4.00 & \multirow{3}{*}{0.431} \\
\hline & UM & & 3.1 & 37.5 & 45.3 & 14.1 & 3.70 & 4.00 & \\
\hline & URM & 0.8 & 3.6 & 29.6 & 50.2 & 15.8 & 3.77 & 4.00 & \\
\hline \multirow{3}{*}{$\begin{array}{l}\text { Solving political and administrative problems } \\
\text { (e.g., improve relations with citizens, } \\
\text { improve/enhance the effectiveness of public } \\
\text { services, fight corruption) }\end{array}$} & CDR & & 3.2 & 9.7 & 38.7 & 48.4 & 4.32 & 4.00 & \multirow{3}{*}{0.058} \\
\hline & UM & 0.8 & 2.3 & 22.7 & 45.3 & 28.9 & 3.99 & 4.00 & \\
\hline & URM & 0.4 & 3.9 & 23.3 & 43.6 & 28.8 & 3.96 & 4.00 & \\
\hline \multirow{3}{*}{$\begin{array}{l}\text { Encouraging economic growth/employment, } \\
\text { attracting investors, creating investment } \\
\text { opportunities }\end{array}$} & CDR & & & 3.1 & 9.4 & 87.5 & 4.84 & 5.00 & \multirow{3}{*}{$0.047^{*}$} \\
\hline & UM & & 0.8 & 5.3 & 22.1 & 71.8 & 4.65 & 5.00 & \\
\hline & URM & 0.8 & 0.8 & 5.8 & 26.1 & 66.5 & 4.57 & 5.00 & \\
\hline \multirow{3}{*}{$\begin{array}{l}\text { Improving local infrastructure, communication } \\
\text { and transport }\end{array}$} & CDR & & & & 29.0 & 71.0 & 4.71 & 5.00 & \multirow{3}{*}{0.898} \\
\hline & UM & & 0.8 & 4.5 & 26.5 & 68.2 & 4.62 & 5.00 & \\
\hline & URM & 0.4 & 0.4 & 3.9 & 26.7 & 68.6 & 4.63 & 5.00 & \\
\hline \multirow{3}{*}{$\begin{array}{l}\text { Revitalising run-down areas through the } \\
\text { modernisation and renovation of buildings and } \\
\text { infrastructure }\end{array}$} & CDR & & & 6.5 & 32.3 & 61.3 & 4.55 & 5.00 & \multirow{3}{*}{0.069} \\
\hline & UM & & & 13.6 & 31.8 & 54.5 & 4.41 & 5.00 & \\
\hline & URM & 1.9 & 1.6 & 12.1 & 39.3 & 45.1 & 4.24 & 4.00 & \\
\hline \multirow{3}{*}{$\begin{array}{l}\text { Revitalising degraded areas through investments } \\
\text { in human and social capital }\end{array}$} & CDR & & & 16.1 & 12.9 & 71.0 & 4.55 & 5.00 & \multirow{3}{*}{$<0.001^{*}$} \\
\hline & UM & & 1.5 & 16.0 & 41.2 & 41.2 & 4.22 & 4.00 & \\
\hline & URM & 2.0 & 5.1 & 20.0 & 41.2 & 31.8 & 3.96 & 4.00 & \\
\hline \multirow{3}{*}{$\begin{array}{l}\text { Improving the integration of minorities (e.g., } \\
\text { ethnic, religious, cultural), and promoting } \\
\text { diversity and tolerance within local communities }\end{array}$} & CDR & 6.5 & 35.5 & 16.1 & 16.1 & 25.8 & 3.19 & 3.00 & \multirow{3}{*}{0.616} \\
\hline & UM & 13.7 & 13.0 & 35.9 & 29.0 & 8.4 & 3.05 & 3.00 & \\
\hline & URM & 13.0 & 17.3 & 36.2 & 26.8 & 6.7 & 2.97 & 3.00 & \\
\hline \multirow{3}{*}{$\begin{array}{l}\text { Responding to global trends (e.g., technological } \\
\text { revolution) }\end{array}$} & CDR & 9.4 & 21.9 & 28.1 & 28.1 & 12.5 & 3.13 & 3.00 & \multirow{3}{*}{0.753} \\
\hline & UM & 6.1 & 15.3 & 39.7 & 34.4 & 4.6 & 3.16 & 3.00 & \\
\hline & URM & 7.1 & 18.4 & 39.2 & 29.0 & 6.3 & 3.09 & 3.00 & \\
\hline \multirow{3}{*}{ Implementating smart city concepts } & CDR & 6.5 & 9.7 & 16.1 & 45.2 & 22.6 & 3.68 & 4.00 & \multirow{3}{*}{$0.001^{*}$} \\
\hline & UM & 5.3 & 13.7 & 40.5 & 29.8 & 10.7 & 3.27 & 3.00 & \\
\hline & URM & 9.8 & 18.1 & 38.6 & 26.8 & 6.7 & 3.02 & 3.00 & \\
\hline
\end{tabular}

Note: LGU—Local Government Unit; M denotes Mean; Me denotes Median; * $p<0.05$; "No answer" omitted. 
The results suggest that the municipality type and affluence is significantly associated with the prioritization of policy/practice areas and interventions related to the stimulation of economic growth, the implementation of smart city concepts, and the revitalisation of degraded areas (Table 6). First of all, the prioritization of "encouraging economic growth/employment, attracting investors, and creating investment opportunities" increases with the affluence of the municipality. In particular the highest priority is given in cities with district rights (87.5\%; score 5 points) and cities with revenues of PLN 100-500 million (82.6\%; score 5 points). The lowest priority is given in the most affluent cities (i.e., >500 PLN million, 66.7\%; score 5 points), which can be possibly explained by the recent economic development in the largest (and richer) Polish cities.

Municipality affluence is also significantly related to the prioritization of the smart city concept, with higher priority given in municipalities with district rights (Table 6) and revenues of over PLN (Polish zlotys) 100 million (Table 7). In particular seven out of ten cities with district rights, and about six out of ten municipalities with a budget of over PLN 100 million consider the implementation of smart city concepts as an important priority (i.e., rating it at least 4 on the 5-point Likert scale).

Revitalisation, especially when connected with investing in human and social capital, is the third policy/practice area and interventions whose prioritization is differentiated by municipality characteristics. From an urban development perspective, its significance is emphasised especially in cities with district rights (Table 6), and with high budget revenues (Table 7). This prioritization might reflect that only such municipalities have the necessary financial resources to undertake revitalization initiatives.

Table 7. Prioritization of policy/practice areas and interventions by municipality budget revenue.

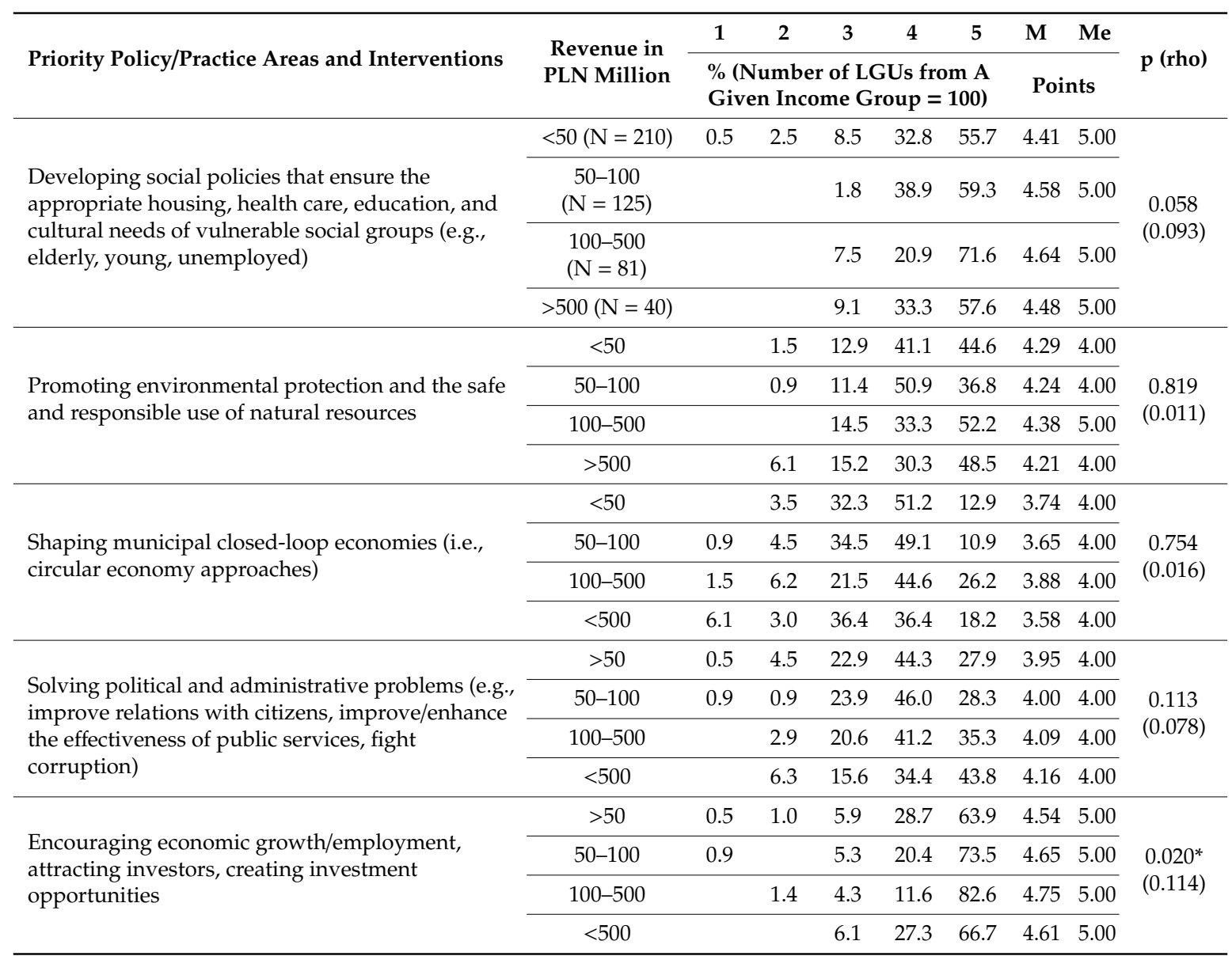


Table 7. Cont.

\begin{tabular}{|c|c|c|c|c|c|c|c|c|c|}
\hline \multirow{2}{*}{ Priority Policy/Practice Areas and Interventions } & \multirow{2}{*}{$\begin{array}{l}\text { Revenue in } \\
\text { PLN Million }\end{array}$} & 1 & 2 & 3 & 4 & 5 & $\mathbf{M}$ & $\mathrm{Me}$ & \multirow{2}{*}{ p (rho) } \\
\hline & & \multicolumn{5}{|c|}{$\begin{array}{l}\% \text { (Number of LGUs from A } \\
\text { Given Income Group = 100) }\end{array}$} & \multicolumn{2}{|c|}{ Points } & \\
\hline \multirow{4}{*}{$\begin{array}{l}\text { Improving local infrastructure, communication } \\
\text { and transport }\end{array}$} & $>50$ & & 0.5 & 4.9 & 27.1 & 67.5 & 4.62 & 5.00 & \multirow{4}{*}{$\begin{array}{c}0.540 \\
(0.030)\end{array}$} \\
\hline & $50-100$ & 0.9 & 0.9 & 0.9 & 30.7 & 66.7 & 4.61 & 5.00 & \\
\hline & $100-500$ & & & 4.3 & 18.8 & 76.8 & 4.72 & 5.00 & \\
\hline & $<500$ & & & 6.1 & 30.3 & 63.6 & 4.58 & 5.00 & \\
\hline \multirow{4}{*}{$\begin{array}{l}\text { Revitalising run-down areas through the } \\
\text { modernisation and renovation of buildings and } \\
\text { infrastructure }\end{array}$} & $>50$ & 1.5 & 1.5 & 12.9 & 40.1 & 44.1 & 4.24 & 4.00 & \multirow{4}{*}{$\begin{array}{l}0.038^{*} \\
(0.101)\end{array}$} \\
\hline & 50-100 & 0.9 & 0.9 & 11.4 & 36.0 & 50.9 & 4.35 & 5.00 & \\
\hline & $100-500$ & 1.4 & & 10.1 & 27.5 & 60.9 & 4.46 & 5.00 & \\
\hline & $<500$ & & & 15.2 & 33.3 & 51.5 & 4.36 & 5.00 & \\
\hline \multirow{4}{*}{$\begin{array}{l}\text { Revitalising degraded areas through investments } \\
\text { in human and social capital }\end{array}$} & $>50$ & 1.5 & 4.0 & 20.8 & 42.1 & 31.7 & 3.99 & 4.00 & \multirow{4}{*}{$\begin{array}{l}0.009^{*} \\
(0.129)\end{array}$} \\
\hline & $50-100$ & 0.9 & 4.5 & 16.1 & 39.3 & 39.3 & 4.12 & 4.00 & \\
\hline & $100-500$ & 1.4 & 2.9 & 10.1 & 42.0 & 43.5 & 4.23 & 4.00 & \\
\hline & $<500$ & & & 28.1 & 15.6 & 56.3 & 4.28 & 5.00 & \\
\hline \multirow{4}{*}{$\begin{array}{l}\text { Improving the integration of minorities (e.g., } \\
\text { ethnic, religious, cultural), and promoting } \\
\text { diversity and tolerance within local communities }\end{array}$} & $>50$ & 11.4 & 15.8 & 40.6 & 25.7 & 6.4 & 3.00 & 3.00 & \multirow{4}{*}{$\begin{array}{c}0.629 \\
(0.024)\end{array}$} \\
\hline & $50-100$ & 14.3 & 17.0 & 30.4 & 31.3 & 7.1 & 3.00 & 3.00 & \\
\hline & $100-500$ & 14.9 & 17.9 & 28.4 & 26.9 & 11.9 & 3.03 & 3.00 & \\
\hline & $<500$ & 9.1 & 27.3 & 24.2 & 18.2 & 21.2 & 3.15 & 3.00 & \\
\hline \multirow{4}{*}{$\begin{array}{l}\text { Responding to global trends (e.g., technological } \\
\text { revolution) }\end{array}$} & $>50$ & 7.4 & 17.7 & 42.9 & 26.6 & 5.4 & 3.05 & 3.00 & \multirow{4}{*}{$\begin{array}{c}0.054 \\
(0.094)\end{array}$} \\
\hline & 50-100 & 3.6 & 23.2 & 40.2 & 28.6 & 4.5 & 3.07 & 3.00 & \\
\hline & $100-500$ & 14.7 & 8.8 & 25.0 & 39.7 & 11.8 & 3.25 & 4.00 & \\
\hline & $<500$ & & 18.2 & 36.4 & 39.4 & 6.1 & 3.33 & 3.00 & \\
\hline \multirow{4}{*}{ Implementing smart city concepts } & $>50$ & 10.0 & 17.5 & 41.5 & 25.0 & 6.0 & 3.00 & 3.00 & \multirow{4}{*}{$\begin{array}{l}<0.001^{*} \\
(0.200)\end{array}$} \\
\hline & $50-100$ & 6.3 & 22.3 & 37.5 & 28.6 & 5.4 & 3.04 & 3.00 & \\
\hline & $100-500$ & 7.2 & 10.1 & 27.5 & 34.8 & 20.3 & 3.51 & 4.00 & \\
\hline & $<500$ & 6.1 & & 33.3 & 42.4 & 18.2 & 3.67 & 4.00 & \\
\hline
\end{tabular}

Note: M denotes Mean; Me denotes Median; rho denotes Spearman's rank correlation coefficient; ${ }^{*} p<0.05$; “No answer" omitted.

When analyzing indices with municipality characteristics, we find significant differences only for W3 (in F-test $p=0.006$ ). The prioritisation of resource regeneration is the highest for cities with district rights $(M=13.81$, STD $=1.35)$, then for urban municipalities $(M=13.25$, STD = 1.67), and finally for urban-rural municipalities $(\mathrm{M}=12.82$, $\mathrm{STD}=2.03)$. However, only cities with district rights and urban-rural municipalities differ significantly in statistical terms. Again, this possibly results from the much greater experience of cities with district rights in the implementation of revitalisation projects and programmes, as well as the larger scale of infrastructure investments.

In summary, our results suggest that most of the municipality characteristics do not affect the prioritization of most policy/practice areas and interventions. This reflects to some extent other studies (e.g., [50]) that emphasised that other factors, such as the quality of leadership, administrative efficiency, and human or social capital, are significant when pursuing sustainable development (Section 3.4).

\subsection{Effect of Management Style and the Prioritization of Policy/Practice Areas and Interventions}

Table 8 outlines the relationship between the preferred management style among respondents, and the articulated priorities of the policy/practice areas and intervention. Spearman's rank correlation coefficients are calculated between the clusters of priorities (i.e., W1-W3, Section 3.2) and preferences for city management styles (Section 2.2). Overall, according to the results there was no explicit reference 
to only one particular management style, with high scores (i.e., 4 or 5) assigned to most (or all) of the different management styles, except for 'loyal politician' whose scores tended to be much lower.

Table 8. Relationship between preferred management style and priorities of policy/practice areas and interventions.

\begin{tabular}{|c|c|c|c|c|c|c|}
\hline \multicolumn{2}{|c|}{ Index } & \multicolumn{5}{|c|}{ The Mayor is Above All } \\
\hline & & $\begin{array}{c}\text { A Loyal } \\
\text { Politician Who } \\
\text { Implements the } \\
\text { Objectives of } \\
\text { His/Her Political } \\
\text { Party }\end{array}$ & $\begin{array}{l}\text { A Visionary and } \\
\text { Strategist Who } \\
\text { Incorporates A } \\
\text { Long-Term } \\
\text { Perspective into } \\
\text { Municipal } \\
\text { Management }\end{array}$ & $\begin{array}{l}\text { An Efficient } \\
\text { Manager Who } \\
\text { Manages the } \\
\text { Municipality }\end{array}$ & $\begin{array}{c}\text { An } \\
\text { Initiator/Coordinator } \\
\text { Who Shapes } \\
\text { Relationships, } \\
\text { Cooperation and } \\
\text { Networks in City } \\
\text { Management }\end{array}$ & $\begin{array}{l}\text { A Leader } \\
\text { Guided by the } \\
\text { Common } \\
\text { Interest and } \\
\text { Solidarity }\end{array}$ \\
\hline \multirow{2}{*}{ W1 } & rho & 0.021 & 0.053 & 0.050 & 0.131 & 0.100 \\
\hline & $\mathrm{p}$ & 0.672 & 0.290 & 0.315 & $0.009 *$ & $0.046^{*}$ \\
\hline \multirow{2}{*}{ W2 } & rho & -0.011 & 0.030 & 0.033 & 0.113 & 0.102 \\
\hline & $\mathrm{p}$ & 0.832 & 0.551 & 0.514 & $0.025 *$ & $0.042 *$ \\
\hline \multirow{2}{*}{ W3 } & rho & -0.046 & -0.019 & 0.036 & 0.077 & 0.109 \\
\hline & $\mathrm{p}$ & 0.357 & 0.697 & 0.463 & 0.121 & $0.029 *$ \\
\hline
\end{tabular}

Note: rho denotes Spearman's rank correlation coefficient; * $p<0.05$; "No answer" omitted.

Preference for the three management styles related to the 'loyal politician', 'visionary and strategist', and 'efficient manager' are not significantly correlated to any of the indices of policy/practice areas and interventions (W1-W3) (Section 3.2). Conversely, there is a positive and significant correlation between the 'common values and solidarity' management style, with all indices, and between the 'initiator/cooperation coordinator' with W1 and W2 (Table 8). This implies that mayors (and executive teams) who prefer (or even possibly adopt) more participatory and solidarity-based management approaches are more likely to prioritise modern policy/practice areas and interventions (as reflected by W1 index, Section 3.2) to tackle new urban sustainability challenges, compared to other management styles. At the same time, cities managed by mayors that identify more strongly with management styles such as 'common values and solidarity' and 'initiator/cooperation coordinator' also tend to prioritise traditional approaches to sustainable development (W2 index), with the strength of the relationship being similar to modern priorities (W1 index). Thus, we can deduce that a management style reflecting solidarity and the common good is more associated with those mayors (and executive teams) who perceive the different urban sustainability policy priorities in a more integrated manner.

\section{Discussion}

\subsection{Synthesis of Main Findings}

Our analysis of the prioritised policy/practice areas and interventions for urban sustainability implies the strong focus towards economic-related approaches (Section 3.2). This prioritisation could be explained by the low economic competitiveness of Polish cities compared to Western European cities. Overall, Polish cities are characterised by lower entrepreneurship, ineffective use of qualified workforce, and ability to create and maintain jobs [73]. The urban competitiveness ranking of European cities covers 159 cities with a population of over 100,000 residents across 26 European countries [74]. Polish cities rank low, with only the capital Warsaw ranking relatively high in the list ( $25^{\text {th }}$ spot). Other major cities such as Katowice, Poznań, Kraków, Wrocław, Gdańsk, Łódź, Bydgoszcz, Lublin, Kielce, Opole, Rzeszów and Olsztyn, all rank below the $100^{\text {th }}$ spot. Furthermore, the prioritisation of interventions to improve local infrastructure (Section 3.2) seems to be a typical attitude among political leaders in other Central and Eastern European countries [61]. 
Other studies on the agenda of European mayors show that they combine economic and social priorities, including, in particular, the provision of social assistance $[61,62,75,76]$ and environmental protection [61]. However, as outlined above Polish leaders assign relatively lower priority for environment-related interventions, compared to economic and social ones. This partially confirms other studies on how local authorities prioritise economic aspects rather than environmental goals [77], and further implies the low awareness of Polish mayors about the emerging urban sustainability challenges in the country and the EU.

Furthermore, respondents do not seem to fully recognise the growing need to integrate minorities and manage cultural diversity (Section 3.2). This possibly reflects the current lack of the implementation of related policies at the national government level. The "Polish Immigrants Integration Policy-Assumptions and Guidelines" (PL: Polska polityka integracji cudzoziemców-założenia i wytyczne) was developed in 2013 but it was never adopted by the Council of Ministers. New guidelines for immigrant integration within Poland's migration policy are expected within 2019. This lack of priority towards policies, practices and interventions aiming to integrate minorities and immigrant might lead to a disadvantaged life in poor and segregated neighbourhoods, as outlined by many studies in the US [78-80]. This is particularly disturbing considering that Poland has experienced a rapid influx of immigrants, especially from Ukraine. Although this phenomenon has not yet become a major problem, the constantly growing migration to Poland is an undisputed fact. This means that Polish municipalities will eventually need to confront how to develop and adopt integration strategies to avoid any negative sustainability outcomes. Currently there are only a few examples of good practices on that front, and mainly from the largest and most affluent cities. For example, in 2016, the city of Gdańsk was the first to create an immigrant integration model [81] that covers the most important social policy issues to fully integrate non-Polish immigrants and facilitate a dignified life. It contains specific actions for aid authorities and institutions, implementation entities, sources of financing, and expected outcomes. Other large cities such as Kraków, Warsaw and Łódź have created similar projects for foreign immigrants. However, apart from these disjointed activities, there are no system solutions in place in Poland.

"Modern" policy/practice areas and interventions such as digitization, smart cities, and the circular economy are quite low on the priority list of Polish mayors (and their executive teams). Currently there are no system solutions in Poland regarding smart cities (Poland lacks an established strategic vision for the development of 5G mobile technologies; even though there were efforts to develop a government strategy '5G for Poland' in 2017, which was subject to consultations in 2018, the final version of the strategy has not been passed as of April 2019), but there is an increasing number of relevant projects. Yet, these encompass initiatives undertaken mainly in large cities and in other domains, such as energy (low-emission economy), transport (intelligent transport systems) and e-government [82], with no comprehensive approach to the implementation of advanced technologies in urban management. Research indicates that only eight out of 16 voivodeship capital cities have the potential to become smart cities [82]. Other cities can have significant potential to become smart, but only in selected areas (e.g., Łódź, in the area of the smart environment). Similarly, shaping municipal economies in closed loops also feature quite low in the priority list (Section 3.2). The circular economy model has just started to attract the attention of decision-makers in the country. Financial resources for the implementation of pilot programmes in this area have recently been added to the budgets of a few select Polish municipalities. However, there are no programme documents or legal acts relating to this economic model, both at the national and local levels.

Interestingly, revitalisation features quite high in the priority of mayors (W3 index, Section 3.2). Attaching importance to urban revitalisation may, in our opinion, result from the legal and organizational framework established in Poland. Since 2015, revitalisation has been a voluntary task for Polish municipalities, governed by a separate act and guidelines from the Ministry of Development. Revitalisation programmes are largely financed by the EU, with the above-mentioned documents specifying precisely how they should be implemented. However, large urban centres are more 
experienced at attracting funds and undertaking revitalization processes, which are increasingly supplemented with investments in human and social capital in an effort to achieve a balance between the material and social dimension of revitalisation. This also reflects the greater scale of social problems in large cities in Poland and their socio-spatial polarisation. Research conducted at the capital cities of Polish voivodeships proved that the higher a city's affluence level, the greater the probability of the concentration of social problems in selected urban areas [83].

Regardless of the legal conditions, implementing some of the above types of policies, practices and interventions (e.g., smart and green solutions) in Polish cities would require leaders with a pro-innovation attitude that are open to modern solutions, and have considerable financial resources [84]. In Poland, only large urban areas that are centres of economic growth, knowledge and innovation generation, and financial capital have these characteristics [51]. This is typical for post-socialist countries and, when compared to Western countries, possibly stems from the delayed structural changes [85]. More favourable and more attractive conditions for production activities, the innovation environment, and the multiplier effect enable the economic development of larger cities, which may result in the shifting of local authorities' political priorities [85]. Due to such development disparities, smaller municipalities tend to prioritise traditional infrastructure investments, which effectively block other projects since they consume already scarce financial resources in smaller cities.

\subsection{Hypotheses and Implications for Local Government}

Based on a literature review and recent studies (Section 1,2.1), we have assumed that Polish mayors, and their executive teams, are not aware of the importance and consequences of new sustainability challenges in Polish cities (Section 2.1). We believe that this lack of awareness affects how mayors (and their executive teams) prioritise policy/practice areas and interventions to solve effectively and inclusively such urban sustainability challenges. The perceptions about the priority assigned to the 11 policy/practice areas and interventions (captured through 5-point Likert scale, Section 3.2, Table 3) and the composite indices W1-W3 (Table 4 and Table 5, Figure 4) clearly reflect both the prioritisation of traditional approaches to sustainable development, and the markedly low interest towards new policy/practice areas and interventions. Considering the emergence of new sustainability challenges (Section 1), this focus on traditional approaches could curtail the effectiveness of urban policies in Polish cities, as well as the competitiveness, quality of life and ultimately the sustainability of these cities.

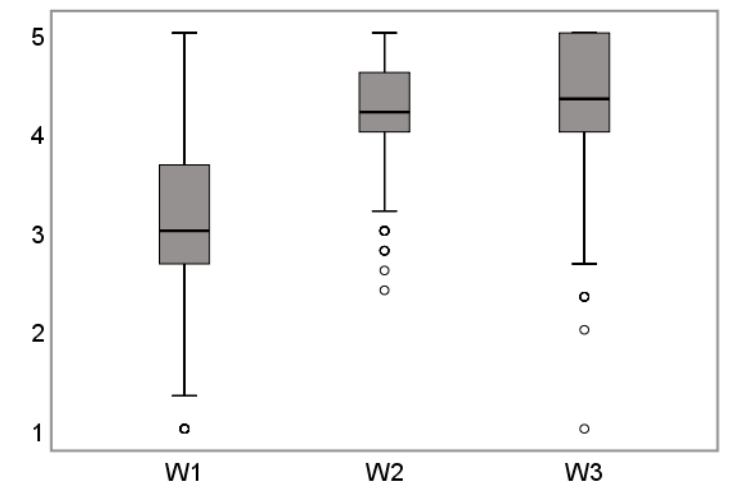

Figure 4. Score comparisons between the three indices (W1-W3).

Additionally, the priorities of Polish mayors (and their executive teams) seem to be aligned with reactive approaches towards "crises" such as air pollution and urban degradation, instead of proactive management that anticipates problems and phenomena that have not yet been resolved in Poland (e.g., integration of migrants, technological innovation). Underestimating the potential of such interventions may preclude progress in Polish cities, and pose a real threat to the development of smart, green and sustainable cities. 
Changing this situation would most likely require an intensive information campaign among local decision-makers, to build local capacity regarding modern methods of enabling sustainable urban development. Moreover, such efforts should be accompanied with the promotion of solidarity and openness to cooperation among local authorities.

When it comes to the two research hypotheses (Section 2.1), our research results partially confirm the Hypothesis 1 (H1) about the prioritisation of less traditional policy/practice areas and interventions in wealthier cities (Section 3.3, Table 6, Table 7). In particular, only for the implementation of smart city concepts, the city's status and budget revenues affect respondents' average assessment. Such a relation has not been confirmed for the rest of the policy/practice areas and interventions, which means that they are perceived in a similar manner between the mayors (and their executive teams) of cities with different levels of affluence. Similar and low assessment is also observed for improving integration and promoting diversity, despite the actual influx of migrants, which, much like other parts of the EU, takes place not only in large cities but also in towns and rural municipalities [86]. It is clear why approaches/interventions for responding to global trends (e.g., technological revolution) are not prioritized, despite expecting it to be more prominent in responses from large cities that have a higher concentration of entities from the innovation and technology sector. Furthermore, the average ratings for "shaping municipal closed-loop economies (i.e., circular economy approaches)" in municipalities of different types and affluence levels are also surprising, considering that the relevant pilot programmes covered non-urbanised areas and ignored large urban municipalities in Poland.

The results for Hypothesis 2 (H2) are more clear-cut. Results in Section 3.4 and Table 8 indeed confirm that Polish mayors (and executive teams) who adopt more participatory and solidarity-based management approaches, are more likely to prioritise modern policy/practice areas and interventions (W1 index) for new urban sustainability challenges, compared to respondents that favor other management approaches. Interestingly, these results remain the same even when omitting responses for non-mayors (i.e., executive teams). Using two-way analysis of variance we can assess the significance of main effect of two variables, namely the type of respondent (mayor/executive team) and the characteristics of the municipality (e.g., type or revenue). This allows for evaluating the actual effect of respondent position, as the assessment of the effect of municipality type or revenue is under the assumption that all respondents have the same position within the study municipalities. The two-way analysis of variance (similar to one-way results), suggests that that there are statistically significant differences for $\mathrm{W} 3$ only between cities with district rights and urban-rural municipalities (the budget revenue remains a non-significant factor). This was probably due to the fact that the questionnaire was aimed directly at the mayors who were asked to fill its first part.

\subsection{Future Research}

Future research should explore whether the prioritization of less traditional policy/practice areas and interventions corresponds to better sustainability performance in the respective cities. Such analyses should consider broader sets of sustainability indicators (e.g., including indicators of technological, ecological and social change) that go beyond the commonly used socio-economic development indicators used in Poland at the local level. These indicators are either too narrow (e.g., do not take into account all relevant aspects of sustainable urban development, Section 1), or they use traditional measures, disregarding advances in the field of sustainability impact assessment. Moreover, such studies should be more comprehensive in their scope, and go beyond the often-limited geographical focus on only certain municipalities in a few voivodships [87-91]. Finally, it would be interesting to use the methodology applied in this study to conduct comparative analyses with other EU countries, as a means of exploring broader patterns within the EU.

\section{Conclusions}

This paper identified the different policy/practice areas and interventions prioritized in different Polish municipalities as a means of solving sustainability challenges, as well as the factors that 
differentiate these priorities. Our analysis implies, that the mayors (and their executive teams) assign higher priority to policy/practice areas and interventions related to economic and social domains, and slightly lower priority to environmental ones. We find that these priorities are grouped into three categories that reflect: (a) new perspectives, (b) traditionalist perspective, and (c) reactive perspective towards urban sustainability. The results also suggest that Polish mayors (and their executive teams) fail to prioritise responses to new sustainability challenges, i.e., those reflected in W1.

The clear prioritization of responses to conventional sustainability challenges (combined with the lower prioritization of some environmental aspects and the digital revolution) indicates a lack of "vision" with respect to sustainable urban development in Polish cities. Although this is typical for all study municipalities, it is more prevalent in smaller cities. This can be explained by the generally lower level of economic development, as well as the lower potential of the respective local economies. This, however, does not necessarily imply that the implementation of sustainable urban development policies, plans, and interventions is threatened, but it definitely reveals the possible dominance of an economic and social (to a limited extent) mindset over an environmental mindset.

Author Contributions: Conceptualization, A.P.-K. and J.P.; Data curation, A.P.-K., J.P. and J.W.; Formal analysis, J.W.; Investigation, A.P.-K. and J.P.; Methodology, A.P.-K. and J.P. and J.W.; Project administration, A.P.-K. and J.P.; Resources, A.P.-K., J.P. and J.W.; Visualization, A.P.-K., J.P. and J.W.; Writing-original draft, A.P.-K. and J.P.; Writing-review \& editing, A.P.-K., J.P. and J.W.

Funding: This research received no external funding.

Acknowledgments: This research was supported by University of Łódź, Poland.

Conflicts of Interest: The authors declare no conflict of interest.

\section{References}

1. Elzerman, K.; Bontje, M. Urban Shrinkage in Parkstad Limburg. Eur. Plan. Stud. 2015, 23, 87-103. [CrossRef]

2. Martinez-Fernandez, C.; Audirac, I.; Fol, S.; Cunningham-Sabot, E. Shrinking Cities: Urban Challenges of Globalization. Int. J. Urban Reg. Res. 2012, 36, 213-225. [CrossRef] [PubMed]

3. Bernt, M. The Limits of Shrinkage: Conceptual Pitfalls and Alternatives in the Discussion of Urban Population Loss. Int. J. Urban Reg. Res. 2016, 40, 441-450. [CrossRef]

4. Haase, A. European cities between shrinkage and regrowth: Current trends and future challenges. In Die Stadt der Zukunft; Tomaschek, N., Fritz, J., Eds.; Waxmann: Münster, Germany, 2015; pp. 89-120, ISBN 978-3-8309-3276-5.

5. Lauf, S.; Haase, D.; Kleinschmit, B. The Effects of Growth, Shrinkage, Population Aging and Preference Shifts on Urban Development-A Spatial Scenario Analysis of Berlin, Germany. Land Use Policy 2016, 52, $240-254$. [CrossRef]

6. Joo, Y.-M.; Hoon Park, S. Overcoming Urban Growth Coalition: The Case of Culture-Led Urban Revitalization in Busan, South Korea. Urban Aff. Rev. 2017, 53, 843-867. [CrossRef]

7. Ganning, J.P.; Tighe, J.R. Moving toward a Shared Understanding of the U.S. Shrinking City. J. Plan. Educ. Res. 2018. [CrossRef]

8. Riffat, S.; Powell, R.; Aydin, D. Future cities and environmental sustainability. Future Cities Environ. 2016, 2. [CrossRef]

9. Li, C.; Song, Y. Government Response to Climate Change in China: A Study of Provincial and Municipal Plans. J. Environ. Plan. Manag. 2016, 59, 1679-1710. [CrossRef]

10. Li, C. Essays on Climate Change Mitigation, Building Energy Efficiency, and Urban Form. Ph.D. Thesis, The University of North Carolina, Chapel Hill, NC, USA, 2018. Available online: https://cdr.lib.unc.edu/ indexablecontent/uuid:f5bb3589-e8e6-465d-89e1-0254f6814faa (accessed on 1 May 2019).

11. United Nations. Transforming Our World: The 2030 Agenda for Sustainable Development. Available online: https://sustainabledevelopment.un.org/ (accessed on 1 May 2019).

12. United Nations. New Urban Agenda. Available online: http://habitat3.org/the-new-urban-agenda/ (accessed on 1 May 2019). 
13. World Health Organization. Global Urban Ambient Air Quality Database, 2018. Available online: http: //www.who.int/airpollution/data/aap_air_quality_database_2018_v12.xlsx?ua=1 (accessed on 9 November 2018).

14. World Health Organization. Global Urban Ambient Air Quality Database, 2016. Available online: https: //www.who.int/phe/health_topics/outdoorair/databases/who-aap-database-may2016.xlsx?ua=1 (accessed on 9 November 2018).

15. Szylko-Skoczny, M.; Duszczyk, M. Three concepts of Polish migration policy. Polityka Społeczna 2010, 7, 1-5.

16. Godlewska, J. Migration and Immigrants in Poland-Scale, Legal Basis, Politics; Polski Komitet Europejskiej Sieci Przeciwdziałania Ubóstwu EAPN: Warszawa, Poland, 2010; pp. 1-35.

17. Central Statistical Office. Demographic Yearbook of Poland, 2018. Available online: https://stat.gov.pl/ obszary-tematyczne/roczniki-statystyczne/roczniki-statystyczne/rocznik-demograficzny-2018,3,12.html (accessed on 4 April 2019).

18. Ministry of Investment and Economic Development. New Priorities of the Government's Migration Policy 2018. Available online: https://www.miir.gov.pl/strony/aktualnosci/nowe-priorytety-rzadowej-politykimigracyjnej (accessed on 4 November 2018).

19. Central Statistical Office. Population Forecast for Years 2014-2050, 2014. Available online: http://stat.gov.pl/obszary-tematyczne/ludnosc/prognoza-ludnosci/prognoza-ludnosci-na-lata-20142050-opracowana-2014-r-,1,5.html (accessed on 4 November 2018).

20. Ministry of Investment and Economic Development. Municipality Survey on Revitalization-Results of the First Edition of the Research, 2017. Available online: https://www.miir.gov.pl/strony/zadania/ polityka-rozwoju-kraju/rewitalizacja/krajowe-centrum-wiedzy-o-rewitalizacji/aktualnosci/badanie-gminw-zakresie-rewitalizacji-wyniki-pierwszej-edycji-badania/ (accessed on 4 November 2018).

21. Ministry of Investment and Economic Development. National Urban Policy 2030; Ministry of Investment and Economic Development: Warszawa, Poland, 2015; ISBN 978-83-7610-579-6. Available online: https: //www.miir.gov.pl/media/11579/Krajowa_Polityka_Miejska_2023.pdf (accessed on 4 November 2018).

22. Calzada, I.; Cobo, C. Unplugging: Deconstructing the Smart City. J. Urban Technol. 2015, 22, 23-43. [CrossRef]

23. Caragliu, A.; Bo, C.D.; Nijkamp, P. Smart Cities in Europe. J. Urban Technol. 2011, 18, 65-82. [CrossRef]

24. Kitchin, R. The Real-Time City? Big Data and Smart Urbanism. GeoJournal 2014, 79, 1-14. [CrossRef]

25. Kummitha, R.K.R.; Crutzen, N. How Do We Understand Smart Cities? An Evolutionary Perspective. Cities 2017, 67, 43-52. [CrossRef]

26. Neirotti, P.; De Marco, A.; Cagliano, A.C.; Mangano, G.; Scorrano, F. Current Trends in Smart City Initiatives: Some Stylised Facts. Cities 2014, 38, 25-36. [CrossRef]

27. Viitanen, J.; Kingston, R. Smart Cities and Green Growth: Outsourcing Democratic and Environmental Resilience to the Global Technology Sector. Environ. Plan. A Econ. Space 2014, 46, 803-819. [CrossRef]

28. Giffinger, R.; Fertner, C.; Kramar, H.; Kalasek, R.; Pichler-Milanovi, N.; Meijers, E. Smart Cities: Ranking of European Medium-Sized Cities; Centre of Regional Science (SRF) Vienna University of Technology: Vienna, Austria, 2007; pp. 10-12. Available online: http://www.smart-cities.eu/download/smart_cities_final_report. pdf (accessed on 4 November 2018).

29. Stawasz, D.; Sikora-Fernandez, D. Good practices of smart management in Polish cities. Studia Miej. 2015, 19, 35-46.

30. Register, R. EcoCities: Rebuilding Cities in Balance with Nature; New Society Publishers: Gabriola, BC, Canadian, 2006; pp. 181-278, ISBN 978-0-86571-552-3.

31. Register, R. Ecocity Berkeley. Building Cities for a Healthy Future; North Atlantic Books: Berkeley, CA, USA, 1993; pp. 3-56, ISBN 978-1-55643-009-1.

32. Kenworthy, J.R. The eco-city: Ten key transport and planning dimensions for sustainable city development. Environ. Urban. 2006, 18, 67-85. [CrossRef]

33. Cheng, H.; Hu, Y. Planning for sustainability in China's urban development: Status and challenges for Dongtan eco-city project. J. Environ. Monit. 2010, 12, 119-126. [CrossRef]

34. Joss, S. Eco-cities: The mainstreaming of urban sustainability-Key characteristics and driving factors. Int. J. Sustain. Dev. Plan. 2011, 6, 268-285. [CrossRef]

35. Jabareen, Y.R. Sustainable Urban Forms: Their Typologies, Models, and Concepts. J. Plan. Educ. Res. 2006, 26, 38-52. [CrossRef] 
36. Girardet, H. Cities, People, Planet: Urban Development and Climate Change, 2nd ed.; John Wiley and Sons: Chichester, UK, 2008; pp. 254-294, ISBN 978-0-470-77270-6.

37. Cugurullo, F. Urban eco-modernisation and the policy context of new eco-city projects: Where Masdar City fails and why. Urban Stud. 2016, 53, 2417-2433. [CrossRef]

38. World Health Organization. Global Age-Friendly Cities: A Guide. 2007. Available online: http://www.who.int/ ageing/publications/age_friendly_cities_guide/en/ (accessed on 3 November 2018).

39. Breheny, M. The Compact City and Transport Energy Consumption. Trans. Inst. Br. Geogr. 1995, 20, 81-101. [CrossRef]

40. Pearsall, H. Staying Cool in the Compact City: Vacant Land and Urban Heating in Philadelphia, Pennsylvania. Appl. Geogr. 2017, 79, 84-92. [CrossRef]

41. Mahriyar, M.Z.; Rho, J.H. The Compact City Concept in Creating Resilient City and Transportation System in Surabaya. Procedia-Soc. Behav. Sci. 2014, 135, 41-49. [CrossRef]

42. Crommelin, L.; Bunker, R.; Troy, L.; Randolph, B.; Easthope, H.; Pinnegar, S. As Compact City Planning Rolls on, a Look Back: Lessons from Sydney and Perth. Aust. Plan. 2017, 54, 115-125. [CrossRef]

43. Salingaros, N.A. Compact City Replaces Sprawl. In Crossover: Architecture, Urbanism, Technology; Graafland, A., Kavanaugh, L., Eds.; 010 Publishers: Rotterdam, The Netherlands, 2006; pp. 100-115, ISBN 978-9064506093.

44. Wittmayer, J.M.; van Steenbergen, F.; Rok, A.; Roorda, C. Governing Sustainability: A Dialogue between Local Agenda 21 and Transition Management. Local Environ. 2016, 21, 939-955. [CrossRef]

45. Wolfram, M.; Frantzeskaki, N. Cities and Systemic Change for Sustainability: Prevailing Epistemologies and an Emerging Research Agenda. Sustainability 2016, 8, 144. [CrossRef]

46. Frantzeskaki, N.; Bach, M.; Mguni, P. Understanding the Urban Context and Its Challenges. In Co-Creating Sustainable Urban Futures: A Primer on Applying Transition Management in Cities; Frantzeskaki, N., Hölscher, K., Bach, M., Avelino, F., Eds.; Springer International Publishing: Basel, Switzerland, 2018; Volume 11, pp. 43-61, ISBN 978-3-319-69271-5.

47. Caldas, P.; Ferreira, D.C.; Dollery, B.; Marques, R.C. Municipal Sustainability Influence by European Union Investment Programs on the Portuguese Local Government. Sustainability 2018, 10, 910. [CrossRef]

48. Navarro-Galera, A.; Alcaraz-Quiles, F.J.; Ortiz-Rodriguez, D. Enhancing Sustainability Transparency in Local Governments-An Empirical Research in Europe. Sustainability 2018, 10, 2161. [CrossRef]

49. United Nations Conference on Environment and Development. Agenda 21, Rio Declaration, Forest Principles; United Nations: New York, NY, USA, 1992; Available online: https://sustainabledevelopment.un.org/ outcomedocuments/agenda21 (accessed on 9 November 2018).

50. Bober, J.; Hausner, J.; Izdebski, H.; Lachiewicz, W.; Mazur, S.; Nelicki, A.; Nowotarski, B.; Puzyna, W.; Surówka, K.; Zachariasz, I.; et al. Increasing Dysfunctions, Fundamental Dilemmas, Necessary Actions. Report on the State of Local Self-Government in Poland; Uniwersytet Ekonomiczny w Krakowie, Małopolska Szkoła Administracji Publicznej: Kraków, Poland, 2013; ISBN 978-83-89410-37-5.

51. Śleszyński, P. Poland of Medium-Sized Cities. Assumptions and Concept of Deglomeration in Poland; Klub Jagielloński: Warszawa, Poland, 2018; Available online: https://klubjagiellonski.pl/publikacje/polskasrednich-miast-zalozenia-i-koncepcja-deglomeracji-w-polsce (accessed on 4 November 2018).

52. Śleszyński, P. Delimitation of Medium-Sized Cities that Are Experiencing Socio-Economic Decline; Instytut Geografii i Przestrzennego Zagospodarowania PAN: Warszawa, Poland, 2016; pp. 1-33.

53. Domański, B. Post-socialism and transition. In Handbook of Local and Regional Development, 1st ed.; Pike, A., Rodriguez-Pose, A., Tomaney, J., Eds.; Routledge: London, UK; New York, NY, USA, 2011; pp. 172-181, ISBN 0-203-84239-1.

54. Loorbach, D. Transition Management: New Mode of Governance for Sustainable Development; International Books: Utrecht, The Netherlands, 2007; ISBN 978-90-5727-057-4.

55. Loorbach, D. Transition Management for Sustainable Development: A Prescriptive, Complexity-Based Governance Framework. Governance 2010, 23, 161-183. [CrossRef]

56. Grin, J.; Rotmans, J.; Schot, J. Transitions to Sustainable Development: New Directions in the Study of Long Term Transformative Change, 1st ed.; Routledge: London, UK; New York, NY, USA, 2011; ISBN 978-0-415-89804-1.

57. Bakker, J.; Denters, B.; Vrielink, M.O.; Klok, P.-J. Citizens' Initiatives: How Local Governments Fill Their Facilitative Role. Local Gov. Stud. 2012, 38, 395-414. [CrossRef] 
58. Wittmayer, J.M.; Schäpke, N.; van Steenbergen, F.; Omann, I. Making Sense of Sustainability Transitions Locally: How Action Research Contributes to Addressing Societal Challenges. Crit. Policy Stud. 2014, 8 , 465-485. [CrossRef]

59. Meadowcroft, J.; Farrell, K.N.; Spangenberg, J. Developing a Framework for Sustainability Governance in the European Union. Int. J. Sustain. Dev. 2005, 8, 3-11. [CrossRef]

60. Rogall, H. Economics of Sustainable Development. Theory and Practice; Zysk i S-ka: Poznań, Poland, 2010; ISBN 978-83-750-6551-0.

61. Cabria, M.; Magnier, A.; Pereira, P. Mayors' Agendas: Emerging Variations on the Theme of Entrepreneurialism. In Political Leaders and Changing Local Democracy: The European Mayor; Governance and Public Management; Heinelt, H., Magnier, A., Cabria, M., Reynaert, H., Eds.; Springer International Publishing: Cham, Switzerland, 2018; pp. 243-272.

62. Magnier, A.; Navarro, C.; Russo, P. Urban Systems as Growth Machines? Mayors' Governing Networks against Global Indeterminacy. In The European Mayor: Political Leaders in the Changing Context of Local Democracy; Bäck, H., Heinelt, H., Magnier, A., Eds.; VS Verlag für Sozialwissenschaften: Wiesbaden, Germany, 2006; pp. 201-219.

63. Budd, L.; Sancino, A. A Framework for City Leadership in Multilevel Governance Settings: The Comparative Contexts of Italy and the UK. Reg. Stud. Reg. Sci. 2016, 3, 129-145. [CrossRef]

64. Hlepas, N.; Chantzaras, T.; Getimis, P. Leadership Styles of European Mayors: How Much Have They Changed Over the Past 12 Years. In Political Leaders and Changing Local Democracy: The European Mayor; Governance and Public Management; Heinelt, H., Magnier, A., Cabria, M., Reynaert, H., Eds.; Springer International Publishing: Cham, Switzerland, 2018; pp. 209-241.

65. Comrey, A.L.; Lee, H.B. A First Course in Factor Analysis, 2nd ed.; Lawrence Erlbaum: Mahwah, NJ, USA, 1993; ISBN 978-1-56321-147-8.

66. Costello, A.B.; Osborne, J.W. Best Practices in Exploratory Factor Analysis: Four Recommendations for Getting the Most from Your Analysis. Pract. Assess. Res. Eval. 2005, 10, 173-178.

67. Kaiser, H.F. An Index of Factorial Simplicity. Psychometrika 1974, 39, 31-36. [CrossRef]

68. Panek, T. Statistical Methods of Multidimensional Benchmarking, 1st ed.; SGH-Oficyna Wydawnicza: Warszawa, Poland, 2009; ISBN 9788373784253.

69. Malarska, A. Statistical Data Analysis Supported by the Program SPSS; SPSS Polska: Kraków, Poland, 2005; ISBN 83-912871-2-2.

70. Malina, A. Multidimensional Analysis of Spatial Diversification of Poland's Economic Structure by Voivodships; Wydawnictwo Akademii Ekonomicznej w Krakowie: Kraków, Poland, 2004; ISBN 83-7252-200-6.

71. Walesiak, M.; Gatnar, E. (Eds.) Statistical Analysis of Data Using the R Program; PWN: Warszawa, Poland, 2009; ISBN 978-83-01-15661-9.

72. Fabrigar, L.R.; Wegener, D.T.; MacCallum, R.C.; Strahan, E.J. Evaluating the Use of Exploratory Factor Analysis in Psychological Research. Psychol. Methods 1999, 4, 272-299. [CrossRef]

73. Szczech-Pietkiewicz, E. Competitiveness of selected Polish cities in the context of cities from other Member States of the European Union. Zesz. Nauk. Szkoła Główna Handlowa. Kol. Gospod. Światowej 2012, 34, 128-150.

74. Sáez, L.; Periáñez, I.; Heras-Saizarbitoria, I. Measuring Urban Competitiveness: Ranking European Large Urban Zones. J. Place Manag. Dev. 2017, 10, 479-496. [CrossRef]

75. Egner, B.; Sweeting, D. Local Councillors in Europe; Urban and Regional Research International; Egner, B., Sweeting, D., Klok, P.-J., Eds.; VS Verlag für Sozialwissenschaften: Wiesbaden, Germany, 2013.

76. Pérez, A.R.; Yáñez, C.J.N.; Clark, T.N. Mayors and Local Governing Coalitions in Democratic Countries: A Cross-National Comparison. Local Gov. Stud. 2008, 34, 147-178. [CrossRef]

77. Bulkeley, H. Cities and the Governing of Climate Change. Annu. Rev. Environ. Resour. 2010, 35, $229-253$. [CrossRef]

78. Ruther, M.; Tesfai, R.; Madden, J. Foreign-Born Population Concentration and Neighbourhood Growth and Development within US Metropolitan Areas. Urban Stud. 2018, 55, 826-843. [CrossRef]

79. Jacobsen, K. The Economic Life of Refugees; Kumarian Press: Bloomfield, CT, USA, 2005; ISBN 978-1-56549-204-2.

80. Jacobsen, K. Refugees and Asylum Seekers in Urban Areas: A Livelihoods Perspective. J. Refug. Stud. 2006, 19, 273-286. [CrossRef]

81. Gdansk City Hall, Social Development Department. Immigrant Intagration Model, Gdańsk 2017. Available online: https://www.gdansk.pl/migracje/immigrant-integration-model,a,67017 (accessed on 14 June 2019). 
82. Sikora-Fernandez, D. Smarter cities in post-socialist country: Example of Poland. Cities 2018, 78, 52-59. [CrossRef]

83. Smętkowski, M.; Płoszaj, A.; Rok, J. Local Concentration of Deprivation in Poland; Centrum Europejskich Studiów Regionalnych i Lokalnych EUROREG; Uniwersytet Warszawski: Warszawa, Poland, 2016.

84. Andrisano, O.; Bartolini, I.; Bellavista, P.; Boeri, A.; Bononi, L.; Borghetti, A.; Brath, A.; Corazza, G.E.; Corradi, A.; de Miranda, S.; et al. The Need of Multidisciplinary Approaches and Engineering Tools for the Development and Implementation of the Smart City Paradigm. Proc. IEEE 2018, 106, 738-760. [CrossRef]

85. Gorzelak, G.; Smętkowski, M. Report of FOR: Regional Development, Regional Policy, 2018. Available online: https://for.org.pl/pl/publikacje/raporty-for/raport-for-rozwoj-regionalny-polityka-regionalna (accessed on 6 March 2019).

86. Grzymala-Kazlowska, A.; Phillimore, J. Introduction: Rethinking Integration. New Perspectives on Adaptation and Settlement in the Era of Super-Diversity. J. Ethn. Migr. Stud. 2018, 44, 179-196. [CrossRef]

87. Arcadis. Ranking of Polish Sustainable Cities, 2018. Available online: www.arcadis.com/RankingMiast (accessed on 4 November 2018).

88. Wspólnota. Success of the Passing Tenure (2010-2014), 2015. Available online: www.wspolnota.org.pl/ fileadmin/.../Nr_22_Ranking_-_sukces_mijajacej_kadencji.pdf (accessed on 4 November 2018).

89. Curulis. Report Summary of the Tenure of Local Self-Government 2010-2014, 2015. Available online: https://www.curulis.pl/pliki/wiedza/20140909_raport_v18.pdf (accessed on 4 November 2018).

90. Arak, P. Knowledge-Based Cities Report; Polska Fundacja im. Roberta Schumana: Warszawa, Poland, 2015; pp. 1-44, ISBN 978-83-88752-04-9.

91. Arak, P.; Kusterka-Jefmańska, M. Sustainable Urban Development; Europolis. Polska Fundacja im; Roberta Schumana: Warszawa, Poland, 2016; pp. 1-44, ISBN 978-83-88752-08-7.

(C) 2019 by the authors. Licensee MDPI, Basel, Switzerland. This article is an open access article distributed under the terms and conditions of the Creative Commons Attribution (CC BY) license (http://creativecommons.org/licenses/by/4.0/). 